\title{
OCCURRENCE AND GROWTH HISTORY OF TEXTURALLY SECTOR-AND SIGMOIDAL-ZONED GARNET IN THE SAN LORENZO SCHISTS IN THE SIERRA NEVADA DE SANTA MARTA MASSIF (COLOMBIA)
}

\author{
Oscar Mauricio Castellanos Alarcón ${ }^{1}$; Carlos Alberto Ríos Reyes² ${ }^{2}$ Carlos Alberto Chacón Avila $^{3}$
}

DOI: http://dx.doi.org/10.18273/revbol.v38n3-2016005 @) (1) అ

Forma de citar: Castellanos, O., Ríos, C., y Chacón, C. 2016. Occurrence and growth history of texturally sector- and sigmoidal-zoned garnet in the San Lorenzo Schists in the Sierra Nevada de Santa Marta massif (Colombia). Boletín de Geología, 38(3): 71-88.

\begin{abstract}
The first occurrence of two-step growth of textural sector- and sigmoidal-zoned garnet of metapelitic rocks of the San Lorenzo Schists in the Sierra Nevada de Santa Marta massif is documented here. This textural type of zoned garnets occurs in the staurolite metamorphic zone of the San Lorenzo Schists. They are generally coarse-grained (up to $2.5 \mathrm{~mm}$ in diameter), and occur in quartz-rich domains. Together with staurolite, garnet is a porphyroblastic mineral in these rocks. Two periods of garnet growth have been observed: (1) a xenoblastic core, with a sector-zoned garnet; and (2) a subidioblastic rim with a sigmoidal-zoned garnet. Garnet preserves chemical zoning, with decreasing $\mathrm{X}_{\mathrm{Mn}}$ and increasing $\mathrm{X}_{\mathrm{Mg}}$ from core to rim (a patch trend), suggesting that garnet grew during increasing temperature. $\mathrm{X}_{\mathrm{Ca}}$ and $\mathrm{X}_{\mathrm{Fe}}$ follow a radial trend. Study of this type of garnet indicates that it has grown during the late emplacement of gabbroic rocks of the Santa Marta Batholith close to the peak regional of metamorphism of the San Lorenzo Schists. During the first steps of garnet growth, it develops a textural sector-zoning, characterized by the cleavage domes, pressure shadows and shearing away cleavage domes, whereas during the last steps a textural sigmoidal-zoned garnet overgrowth occurred after textural sector-zoned garnet. This type of textural sector- and sigmoidal-zoned garnet from the San Lorenzo Schists is very important as a key piece for interpretation of the tectono-metamorphic history of this metamorphic unit.
\end{abstract}

Keywords: San Lorenzo Schists, two-step growth, sector- and sigmoidal-zoned, garnet, metamorphism.

\section{OCURRENCIA E HISTORIA DE CRECIMIENTO DE GRANATE CON ZONACION TEXTURAL SECTORIAL Y SIGMOIDAL EN LOS ESQUISTOS DE SAN LORENZO EN EL MACIZO SIERRA NEVADA DE SANTA MARTA (COLOMBIA)}

\section{RESUMEN}

Se documenta aquí la primera aparición de dos etapas de crecimiento del granate con zonación textural sectorial y sigmoidal de las rocas metapelíticas de los Esquistos de San Lorenzo en el Macizo Sierra Nevada de Santa Marta. Este tipo textural de granates zonados ocurren en la zona metamórfica de la estaurolita de los Esquistos de San Lorenzo. Estos son generalmente de grano grueso (hasta $2.5 \mathrm{~mm}$ de diámetro), y se producen en bandas ricas en cuarzo. Al igual la estaurolita, el granate es un mineral porfidoblástico en estas rocas. Se han observado dos períodos de crecimiento del granate: (1) un núcleo xenoblastico, con granate de zonación sectorial; y (2) un borde subidioblastico con granate de zonación sigmoidal. El granate conserva su zonación química, con la disminución de $\mathrm{X}_{\mathrm{Mn}} \mathrm{y}$ el aumento de $\mathrm{X}_{\mathrm{Mg}}$ desde el núcleo hasta el borde (una tendencia en parche), lo que sugiere que el granate creció durante un aumento de la temperatura. $\mathrm{X}_{\mathrm{Ca}} \mathrm{y}_{\mathrm{Fe}}$ siguen una tendencia radial. El estudio de este tipo de granate indica que este creció durante el emplazamiento tardío de rocas gabroides del Batolito de Santa Marta cerca al pico de metamorfismo regional de los Esquistos de San Lorenzo; durante las primeras etapas de crecimiento del granate, este desarrolla una zonación sectorial textural, caracterizado por domos de clivaje, sombras de presión y separación de domos de clivaje debido a cizallamiento, mientras que durante las últimas etapas ocurrió un sobrecrecimiento de granate con zonación sigmoidal texural después de un crecimiento del granate con zonación sectorial textural. Este tipo de crecimiento del granate con zonación textural sectorial y sigmoidal observado en los Esquistos de San Lorenzo es muy importante como una pieza clave para la interpretación de la historia tectono-metamórfico de esta unidad metamórfica.

Palabras clave: Esquistos de San Lorenzo, dos etapas de crecimiento, zonación sectorial y sigmoidal, granate, metamorfismo.

${ }^{1}$ Programa de Geología, Universidad de Pamplona, Colombia, oscarmca@yahoo.es

22 Escuela de Geología, Universidad Industrial de Santander, Colombia, carios@uis.edu.co

${ }^{3}$ Escuela de Fïsica, Universidad Industrial de Santander, Colombia, carlosalbertoch@gmail.com 


\section{INTRODUCTION}

Garnet porphyroblasts in metamorphic rocks provide valuable information on the processes of crystal nucleation and growth for two reasons (Miyashita, 1996): (1) they usually contain internal textural zones and inclusion trails that aid in correlating the timing of garnet growth under specific conditions with deformation and metamorphism (e.g., Hollister, 1966; Andersen, 1984; Rice and Mitchell, 1991; Williams, 1994; Bell et al., 1997; Stallard and Hickey, 2002; Meth and Carlson, 2005; Kim and Jung, 2010; Kiers, 2013), and (2) they have distinct chemical zoning retaining a record of their growth history (e.g., Olimpio and Anderson, 1978; Takasu, 1986; Stallard and Hickey, 2002; Meth and Carlson, 2005; Stowell et al., 2011) and showing some of the greatest variability in terms of solid solution, providing data to constrain the P-T-t evolution of metamorphism in orogenic belts (e.g., Florence and Spear, 1993; Ratner and Cheney, 2002).

Several occurrences of textural sector-zoning in garnet have been reported (e.g., Andersen, 1984; Burton, 1986; Rice and Mitchell, 1991; Miyashita, 1996; Castellanos, 2001; Castellanos et al., 2004; Kohn, 2004; Wilbur and Ague, 2006; Stowell et al., 2011). According to Stowell et al. (2011), sector-zoning should be referred to compositional zones that are systematically related to crystallographic orientations in the crystal, and, therefore, these zones can be directly related to the external crystal faces that formed during garnet growth. However, rare detailed studies on compositional sectorzoning in garnet have been developed (e.g., Stowell et al., 2011). According to Kohn (2004), sector-zoning can be attributed to an intracrystalline compositional difference in regions whose chemical boundaries are crystallographically defined. It has been traditionally associated to differences in chemical partitioning for different crystal faces (e.g., Hollister, 1970), preserved due to crystal growth rates that are rapid compared to intracrystalline diffusion (Watson and Liang, 1995; Watson, 2004). Sector-zoning in garnet shows radial variation along intersections of crystal faces belonging to one form (Argles et al., 1999; Wilbur and Ague, 2006) and variation along faces belonging to different morphologies (Kohn, 2004). According to Kitamura et al. (1993), sector-zoning in garnet can be attributed to compositional changes to reflect element distribution depending upon the curvature of growing garnet surfaces under disequilibrium conditions. Therefore, this type of garnet will generate two problems: the cause and extent of the disequilibrium conditions, and the stage at which the sector-zoned garnet grew in the history (Wilbur and
Ague, 2006). Although oscillatory and sector-zoning usually occur in skarns and other contact metamorphic settings (e.g., Akizuki, 1984), neither type of zoning is especially common in regional metamorphic minerals (Kohn, 2004). According to Kohn (2004), sector-zoning in metapelitic rocks is very important because it reflects unusually rapid heating associated with slip along a major thrust fault system, and may be used to infer kinetic parameters of geologic significance. On the other hand, garnet porphyroblasts with sigmoidal inclusion trails are not a common feature of regional metamorphic rocks. According to Ikeda et al. (2002), the sigmoidal trends are commonly very similar in composition and show good continuation with the external foliation, suggesting that they represent foliation that has been incorporated within the garnet during its growth. They have traditionally been attributed to syn-growth rotation of the porphyroblast relative to the stretching axes of the instantaneous strain ellipse (e.g., Masuda and Mochizuki, 1989; Gray and Busa, 2007).

Internal changes from sector-zoning to sigmoidal zoning during growth are attributed to cessation of crystal growth on dodecahedral faces and later growth on trapezohedral faces (Sepahi, 2007.). This change may have occurred during decreased overstepping of equilibrium reaction temperatures. Garnet is stable over a wide range of PT conditions and is of particular interest to obtain knowledge of its deformation mechanisms, although its deformation behaviour has been controversially discussed (e.g., Vernon, 1978; Zhao et al., 2004; Bestmann et al., 2008), and the focus of concern is how porphyroblasts grow during deformation and metamorphism.

There is considerable debate in the interpretation of garnet microstructures with respect to plastic deformation versus diffusion processes controlling deformation of garnet under natural conditions (Den Brok and Kruhl, 1996). In regional metamorphic rocks, the partitioning of deformation into progressive shearing and shortening components results in the fact that garnet porphyroblasts cannot nucleate and grow in zones of active progressive shearing, as they would be dissolved by the effects of shearing strain on their boundaries (e.g., Bell et al., 1986). Castellanos et al. $(2004,2010)$ report several examples of tectonic dissolution of garnet.

We report for the first time a two-step growth of textural sector- and sigmoidal-zoned garnet in the San Lorenzo Schists at the Sierra Nevada de Santa Marta massif. In this paper, we reveal a remarkable discovery, using detailed microstructural observations on garnet from 
the San Lorenzo Schists not only to illuminate the mechanisms by which such garnets grow and relative time of formation but also to satisfactorily understand the metamorphic history and the succession of deformation phases of the San Lorenzo Schists.

\section{GEOLOGICAL SETTING}

The Sierra Nevada de Santa Marta massif is an isolated triangular mountain range apart from the Colombian Andes chain, which is bounded by the Oca fault, Santa Marta-Bucaramanga fault and Cesar lineament. It consists of three geological provinces (Sierra Nevada, Sevilla and Santa Marta) with characteristic crystalline basement that differ petrographically and geochronologically (FIGURE 1).

The Sierra Nevada province is bounded on the east by the Cesar lineament and on the west by the Seville lineament; it is composed of metamorphic rocks of Grenvillian age, which have been intruded by granitoid rocks of Jurassic age (Bustamante et al., 2009). Most of this province is covered by Jurassic volcanic rocks (Tschanz et al., 1974; Restrepo-Pace et al., 1997; Ordoñez et al., 2002; Cordani et al., 2005). The Province of Sevilla is bounded on the east by the Seville lineament and on the west by the Guachaca fault; it is composed of mylonitic granitoids and amphibole and micaschists of Paleozoic age (Tschanz et al., 1969, 1974; Cardona et al., 2006). The Province of Santa Marta is bounded on the east by the Guachaca fault and on the northwest by the Caribbean coastline; it is composed of two metamorphic belts (Tschanz et al., 1969, 1974), which are separated by a wide belt of Paleogene granitoids (Tschanz et al., 1974). The inner belt consists of amphibolites, micaschists and orthogneisses (Gaira, San Lorenzo and undifferentiated schists). The outer belt consists of amphibolites, greenschists and phyllites (Santa Marta schists), which have been considered an allochthonous fragment probably accreted during the Meso-Cenozoic time (Tschanz et al., 1969, 1974; Doolan, 1970; Cardona et al., 2006). The latter was subdivided into four main geological units with stratigraphic connotation known as Concha, Punta Betín, Cinto and Rodadero formations.

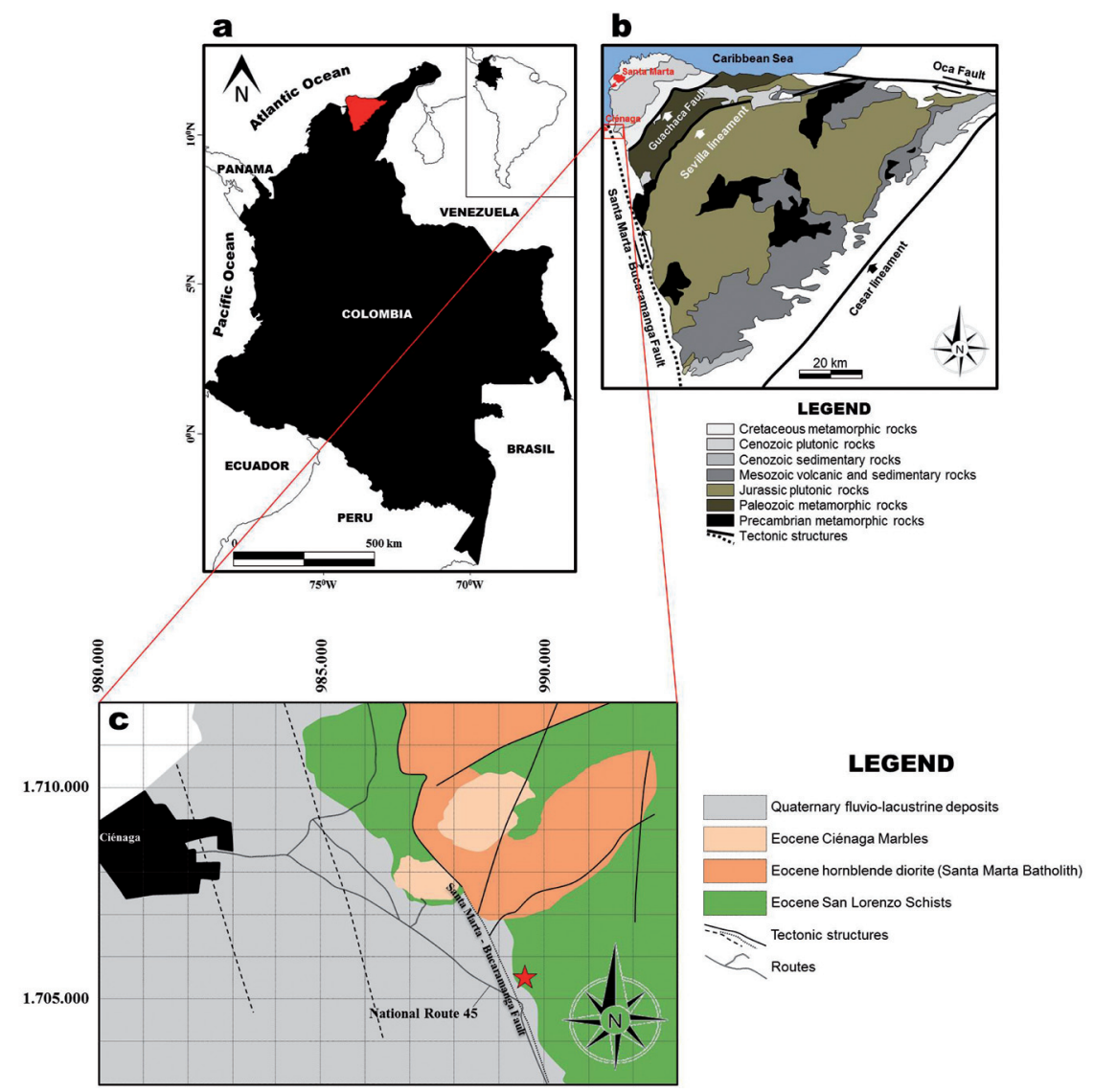

FIGURE 1. (a) General sketch of the localization of the Sierra Nevada de Santa Marta massif in Colombia (South America). (b) Generalized geologic map of the Sierra Nevada de Santa Marta massif (modified after Tschanz et al., 1974), showing the location of the study area (red box). (c) Generalized geologic map of the study area, showing distribution of the San Lorenzo Schists. Red star indicates the occurrence of textural sector-zoning and sigmoidal inclusion pattern garnet. 
Tschanz et al. (1969) introduced the term San Lorenzo Schists for a metapelitic sequence that crops out in the Sierra Nevada de Santa Marta massif with a general strike of $\mathrm{N} 15-25^{\circ} \mathrm{E}$ and dip $30-40^{\circ} \mathrm{SE}$. Cardona et al. (2010) suggests that sedimentary deposition of the protolith of the San Lorenzo Schists took place after the Middle Jurassic, based on U-Pb zircon geochronology. A metamorphism age of $49.1 \pm 6.4 \mathrm{Ma}$ by $\mathrm{K} / \mathrm{Ar}$ geochronology in amphibole has been given by Tschanz et al. (1969). Here, this metamorphic unit consists of micaschists, micaceous quartzites, quartz-feldspar micaschists and amphibole and graphite schists. The micaschists of interest in this study are characterized
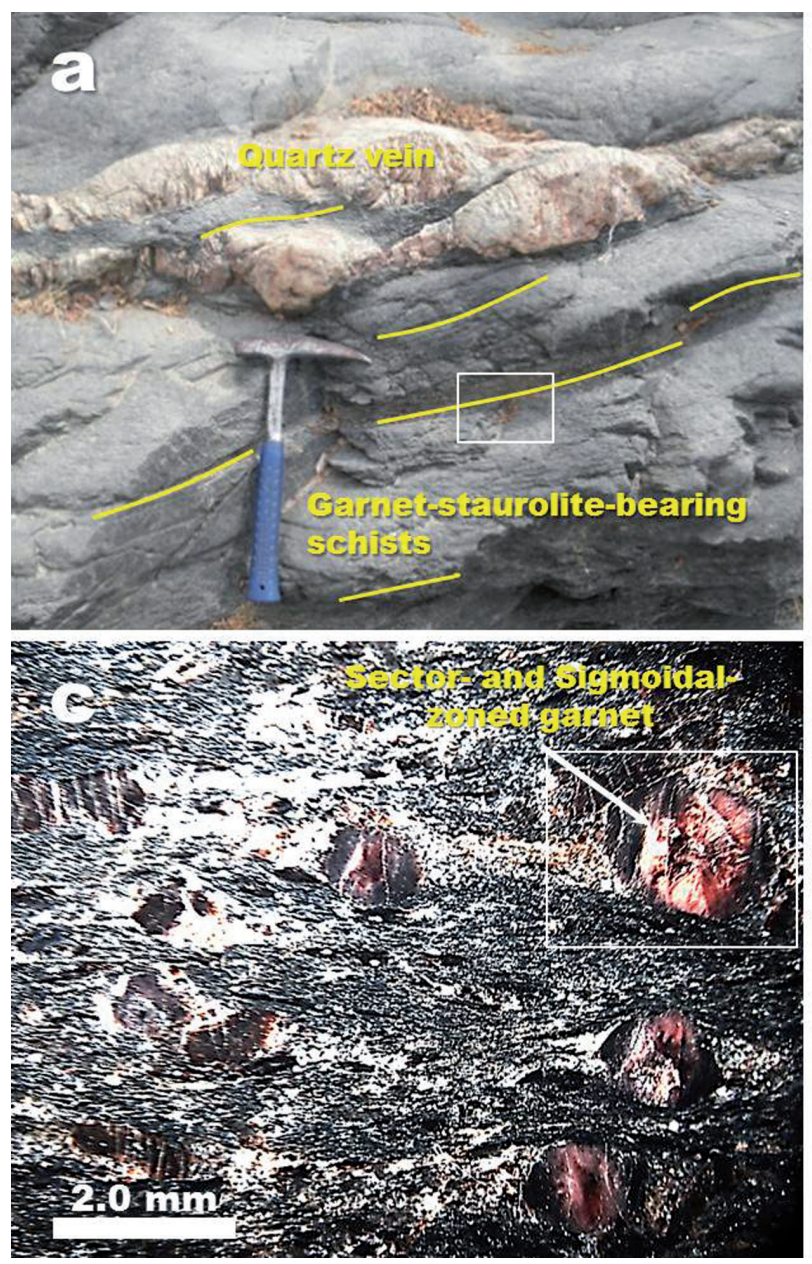

by the presence of garnet and staurolite porphyroblasts, muscovite, biotite, quartz, ilmenite and graphite.

The San Lorenzo Schists are mainly composed of garnetquartz-micaschists with a penetrative northeast-striking schistosity (FIGURE 2). This schistosity is sub-parallel to the axial planes of matrix crenulations and isoclinal folds outlined by quartz veins, and is itself openly folded and locally crenulated, with incipient development of an axial plane foliation. No large mesoscopic fold hinges in any foliation or lithological layering were observed. This metamorphic unit has been affected by Barroviantype metamorphism that reached the staurolite zone.
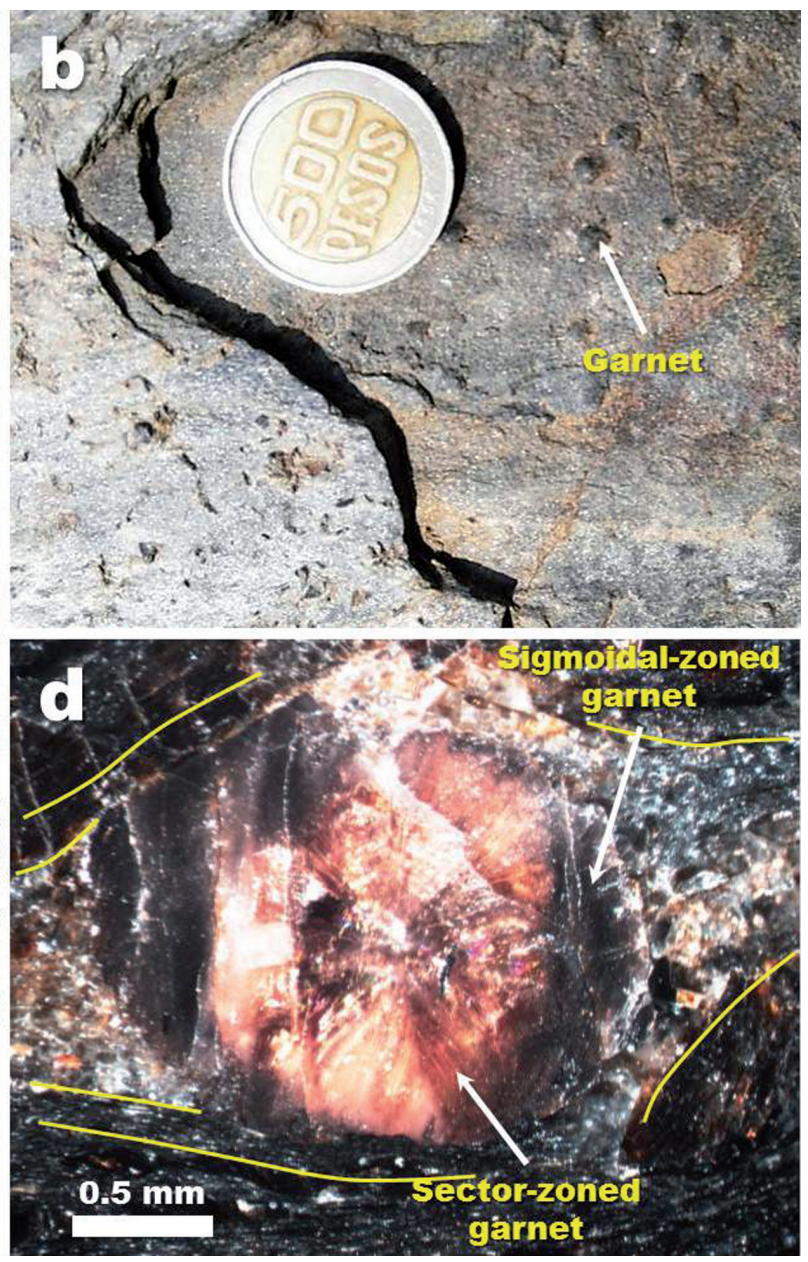

FIGURE 2. (a)-(b) Photographs of the San Lorenzo Schists at outcrop scale: Note the occurrence of numerous garnet porphyroblasts in the garnet-staurolite-bearing micaschists. (c)-(d) Stereophotographs of the sector- and sigmoidal-zoned garnet, wrapped by the main foliation of the rock.

\section{ANALYTICAL PROCEDURES}

The studied garnet-staurolite-bearing micaschist was collected in one outcrop located in the intersection of between the National Roadway 90 and the Aguja River (geographic coodinates $\mathrm{X}=989.746$ y $\mathrm{Y}=1.703 .526$ ), and belongs to the San Lorenzo Schists (Sierra Nevada de Santa Marta massif). The sample was cut parallel to the lineation and perpendicular to the foliation in the rock to obtain a polished thin section (cutting 
through garnets are not necessarily central sections). The mineral composition and mineral assemblage, with emphasis on textural relationships between mineral phases, were established in an Olympus BX-51 trinocular microscope, and the photomicrographs were taken using a high resolution Nikon microphotographic system of 5.5 MegaPixels and software Nikon NISElements Br. Mineral abbreviations are after Kretz (1983). Scanning electron microscopy (SEM) imaging and energy dispersive spectroscopy (EDS) were carried out by environmental scanning electron microscopy (FEI Quanta 650 FEG ESEM) to examine the mineral phases' textures and cross-cutting relationships in the garnet-staurolite-bearing micaschist, under the following analytical conditions: magnification $=100$ $800 \mathrm{x}$, working distance $(\mathrm{WD})=9.6-10.2 \mathrm{~mm}$, high vaccum $(\mathrm{HV})=30 \mathrm{kV}$, signal = atomic number contrast (Z CONT), back scatter electron detector (BSED). The calculation of $\mathrm{wt} \%$ oxides was carried out using a spreadsheet, taking into account the atomic\% (from EDS), the specific formula of each oxide, and the number of non-oxygen atoms. Compositional zoning of garnets was analyzed using color mapping under the following conditions: image resolution $=256 \times 200$ pixels; magnification $=120-270 \mathrm{x} ; \mathrm{HV}=30 \mathrm{kV}$; dwell time $=200-500 \mathrm{~ms}$.

\section{PETROGRAPHY}

The San Lorenzo Schists are foliated, medium- to coarse-grained, pelitic rocks that generally show a millimeter-scale compositional banding consisting of alternation of lepidoblastic muscovite-biotite domains and coarse-grained granoblastic quartz-rich microlithons. The schistosity is mainly due to the alignment of individual grains of phyllosilicates and Fe-Ti oxides. The typical mineral assemblage is quartz + muscovite + biotite + garnet + staurolite (with minor apatite, zircon, graphite and Fe-Ti oxides). Garnet occurs as shattered porphyroblasts (up to $2.5 \mathrm{~mm}$ diameter) along with staurolite in a mica rich matrix. Mica and ilmenite parallel to the regional foliation wrap around garnet, whereas quartz and scarce mica flakes occur in strain pressure shadows. The small scale folding of the schistosity plane produced crenulation cleavage, accompanied by segregation of quartz into horizontal layers. Schistosity surrounds the porphyroblasts of garnet and staurolite. These pelitic rocks have been affected by multiple deformation phases giving rise to interference patterns. Petrographic and microstructural evidence indicate that they are multiply deformed with at least three deformational events $\left(D_{1}, D_{2}, D_{3}\right)$, which progressively generated three schistosities $\left(\mathrm{S}_{1}, \mathrm{~S}_{2}, \mathrm{~S}_{3}\right)$ as illustrated in FIGURE 3. However, the recognized deformational events and schitosities do not represent different metamorphic events and so they might occur during a single event. The rock of interest in this study corresponds to a crenulated garnet-staurolite-bearing micaschist with numerous garnet and staurolite porphyroblasts, biotite, muscovite, quartz and plagioclase as the major constituents and minor opaque minerals (graphite and ilmenite) in the matrix.

\section{OCCURRENCE OF GARNET}

\section{Textural types of garnet}

Photomicrographs of the textural features of the twostep growth of textural sector- and sigmoidal- zoned garnet of the San Lorenzo Schists are shown in FIGURE 4. The typical garnet-staurolite-bearing micaschist is characterized by the presence of sub-spherical garnet porphyroblasts, which contains a complex textural sector- and sigmoidal-zoned geometry. They show texturally distinct cores and rims, with textural sectorzoning garnet in the core and sigmoidal-zoning garnet in the rim. The transition between core and rim of garnet porphyroblasts is characterized by the truncation of the inclusion pattern. Coarse-grained (up to $2.5 \mathrm{~mm}$ in diameter) garnet porphyroblasts do not show texturally sector-zoned cores.

Several studies report the occurrence of sector-zoned garnets (e.g., Miyashita, 1996; Kohn, 2004; Wilbur and Ague, 2006; Rice et al., 2006; Stowell et al., 2011), which are divided into a series of pyramids, the bases of which form the crystal faces. According to Miyashita (1996), within each pyramid, inclusions form as bundles of slightly misoriented units aligned normal to the crystal face. A relatively complex sectorzoning pattern can be observed, according to the orientation of the section through the crystal, which can explain the different textural types of garnet observed in the San Lorenzo Schists. Sector-zoning is generally unexpected in garnet because it is cubic and the most common $\{011\}$ faces are crystallographically and hence energetically identical. Therefore, it is particularly important that the high-Ca and lowCa sectors reflect distinct crystal faces, commonly $\{112\}$ versus $\{011\}$ (Kohn, 2004). In this study, we report several textural types of garnets, based on the forms and outlines of the sectored parts and inclusion patterns. 

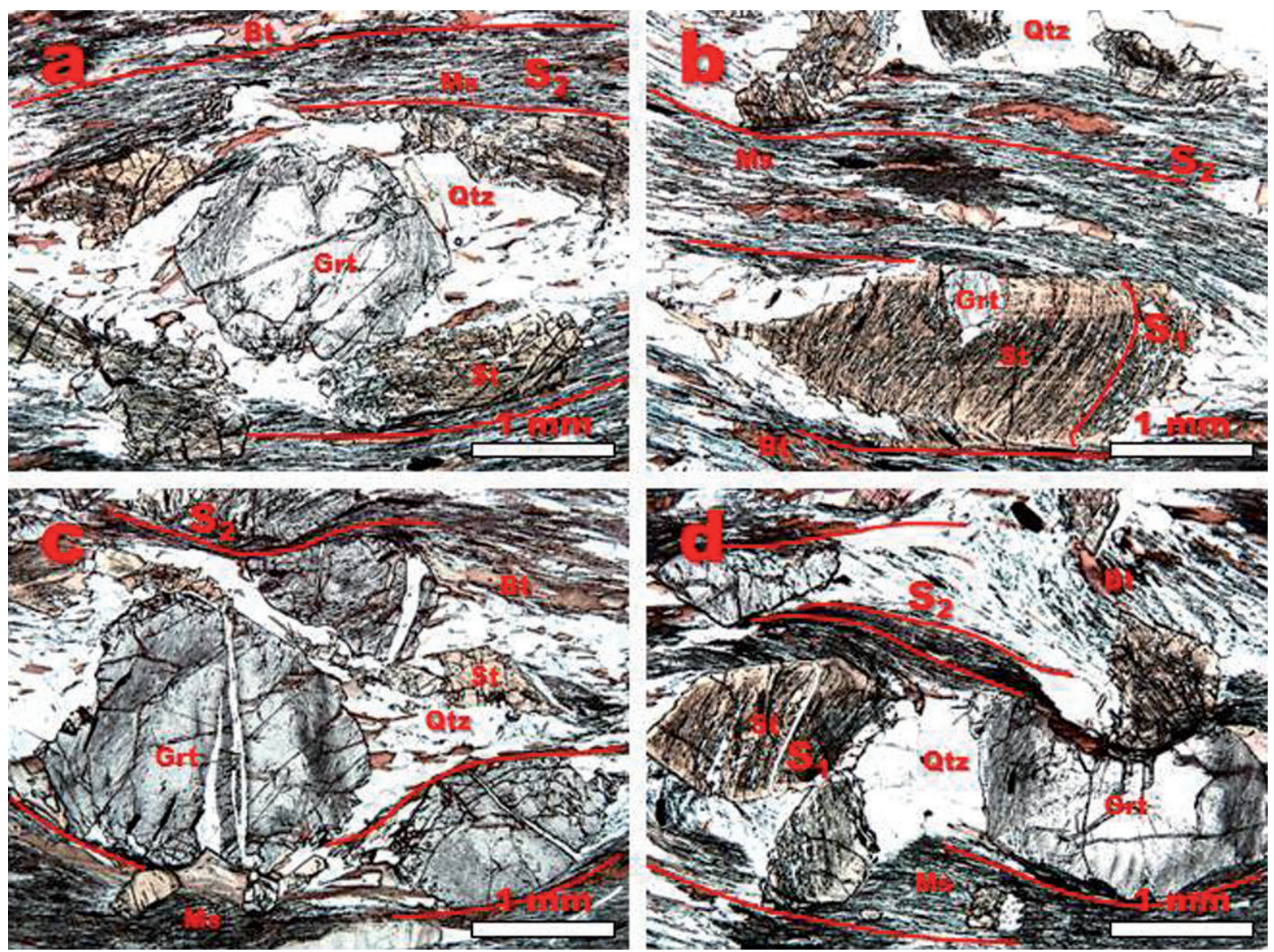

FIGURE 3. Photomicrographs in plane-polarized light of the studied garnet-staurolite-bearing micaschist of the San Lorenzo Schists, illustrating their typical textural features and the relationship of foliations and mineral growth. (a) Pseudo-hexagonal textural sector- and sigmoidal-zoned garnet associated to staurolite, which are wrapped by the main foliation $\left(\mathrm{S}_{2}\right)$ of the rock developed by muscovite and biotite domains, developing strain pressure shadows; (b) small garnet partially included in staurolite porphyroblast, which displays a sigmoidal pattern of inclusions of quartz and ilmenite $\left(\mathrm{S}_{1}\right)$ discordant with $\mathrm{S}_{2}$; (c) irregular garnet porphyroblasts, which display tectonic dissolution and are cross cut by quartz veinlets; (d) garnet porphyroblasts showing strong tectonic dissolution and staurolite porphyroblasts with a sigmoidal $\mathrm{S}_{1}$ discordant with $\mathrm{S}_{2}$. The $\mathrm{S}_{3}$ schistosity (not shown here) is evidenced by scarce flakes of mica at about $30^{\circ}$ with the main schistosity of the rock.

The features of each type of garnet (FIGURE 5) are described in detail below, revealing not only the morphological type of garnet but also that the sections do not intersect porphyroblast centre. FIGURE 5a displays a small idioblastic textural sector-zoned garnet, without sigmoidal pattern of zoning, partly included in a staurolite porphyroblast, which contains a pattern of inclusions of quartz and ilmenite concordant to the main foliation of the rock. Large subidioblastic (pseudo-hexagonal) textural sector- and sigmoidal-zoned garnet porphyroblasts are shown in FIGURES 5b-5e. Note the sectored core including tubular quartz radially arranged without penetration of crenulated $\mathrm{S}_{1}$ mainly developed by quartz and ilmenite. A similar arrangement of inclusions in the textural sector- and sigmoidal-zoning pattern is observed in large subidioblastic (pseudo-tetragonal) (FIGURE 5f) and xenoblastic (amoeba) (FIGURE 5g) garnet porphyroblasts.
FIGURES $5 \mathrm{~h}-5 \mathrm{j}$ show large subidioblastic to xenoblastic garnet porphyroblasts, displaying a strong influence of tectonic dissolution. Note the penetrative non crenulated (FIGURE 5h) and crenulated (FIGURE 5i) $\mathrm{S}_{1}$ defined by a pattern of inclusions of quartz and ilmenite at about $90^{\circ}$ to the main schistosity $\left(\mathrm{S}_{2}\right)$, and the penetrative non crenulated $\mathrm{S}_{1}$ defined by straight quartz and ilmenite trails at approximately $30^{\circ}$ to the main schistosity $\left(\mathrm{S}_{2}\right)$ (FIGURE 5i). A xenoblastic garnet porphyroblast, displaying scarce quartz and ilmenite inclusions without developing a regular pattern of distribution is shown in FIGURE $5 \mathrm{k}$. Note the strong influence of rotation of garnet. A subidioblastic garnet porphyroblast, displaying a pattern of inclusions of quartz and ilmenite $\left(\mathrm{S}_{1}\right)$ concordant to the main schistosity $\left(\mathrm{S}_{2}\right)$ is shown in FIGURE 51 . Note the staurolite porphyroblasts surrounding garnet which also show a similar pattern of inclusions. 

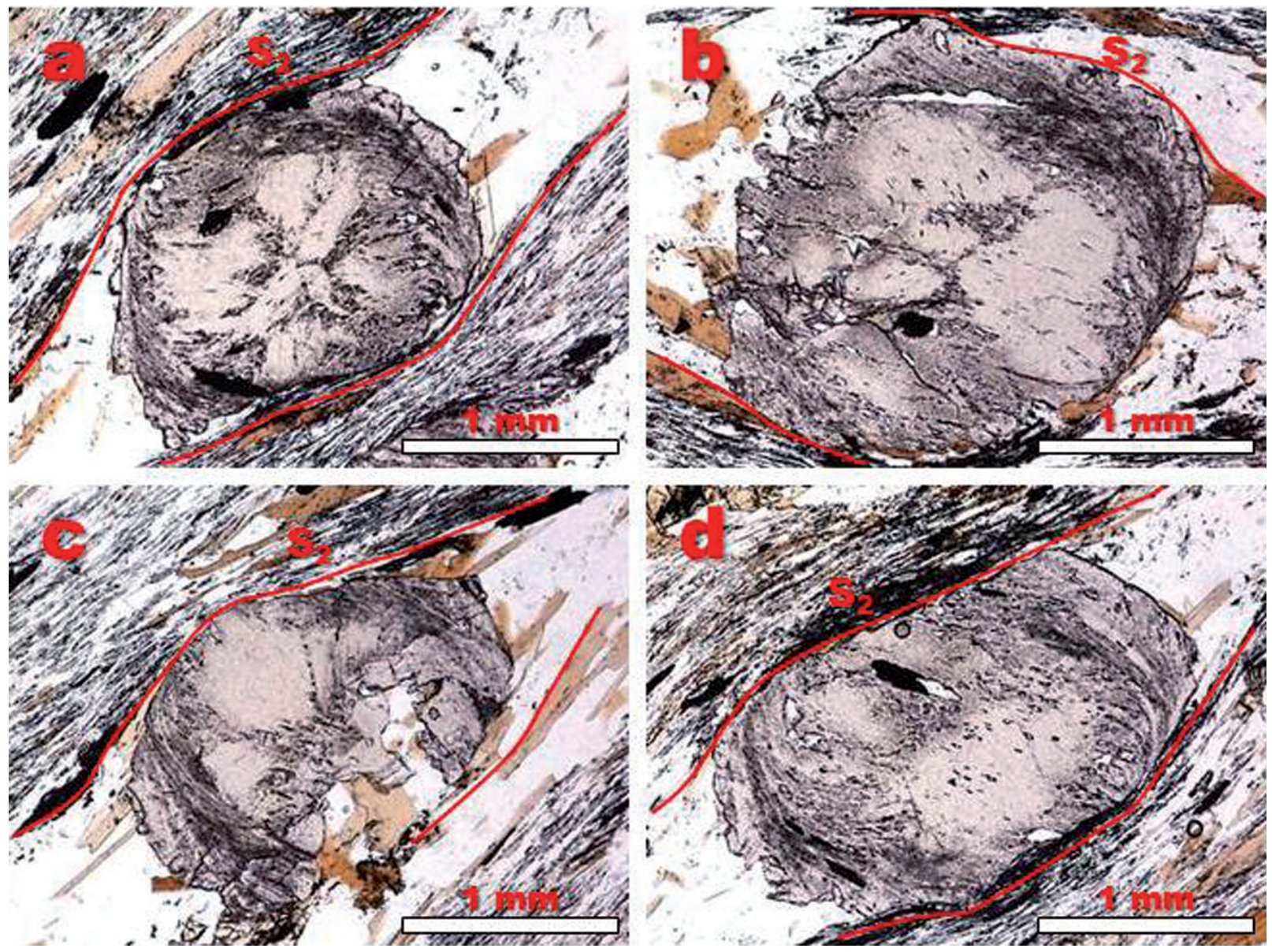

FIGURE 4. Photomicrographs in plane-polarized light of the studied garnet-staurolite-bearing micaschist of the San Lorenzo Schists, with textural sector-zoning and sigmoidal garnet porphyroblasts displaying a number of distinctive microstructural and morphological features. All garnet can be divided into a textural core (sector-zoned garnet) and rim (sigmoidal-zoned garnet), with the transition marked by a sudden change in the pattern of distribution of inclusions. Note the external rim, which grew after sigmoidal-zoned garnet and the main foliation $\left(\mathrm{S}_{2}\right)$ of the rock wrapping around the garnet porphyroblasts, developing strain pressure shadows: (a) pseudo-hexagonal and symmetric garnet; (b) pseudo-hexagonal and asymmetric garnet; (c) and (d) symmetric and asymmetric garnet, respectively, displaying strong tectonic dissolution.

\section{Textural sector- and sigmoidal-zoned garnet}

A two-step growth of textural sector- and sigmoidalzoned garnet in garnet-staurolite-bearing schists of the San Lorenzo Schists can be recognized, with a xenoblastic inner zone (core), which displays textural sector-zoning, with a tubular quartz radially arrangement and a xenoblastic outher zone (rim) with a sigmoidal pattern of inclusions mainly of quartz and ilmenite. The textural transition between core and rim is clearly better observed under transmitted light microscopy than under scanning electron microscopy.

Textural sector-zoning in garnet from these rocks is similar to that reported by several authors (e.g., Kohn, 2004; Wilbur and Ague, 2006; Stowell et al., 2011).
According to Andersen (1984), texturally sector-zoned garnets from graphitic schists can display two types of inclusions: type-1 inclusions and type-2 inclusions (or more properly intergrowths, according to Burton, 1986), which also have been observed from garnet in metapelitic rocks of the San Lorenzo Schists (FIGURE 6).

Type-1 blobby inclusions of quartz, Fe-Ti oxides (ilmenite) and graphite are usually observed along the pyramid interfaces and were derived from the matrix. Type-2 tubular inclusions of quartz that are not relicts of the matrix, but have formed simultaneously with garnet growth, form an angle of $30^{\circ}$ with the pyramid interfaces and of $\sim 90^{\circ}$ with the base of the pyramid within which they formed, although they may be somewhat curved (Burton, 1986). 

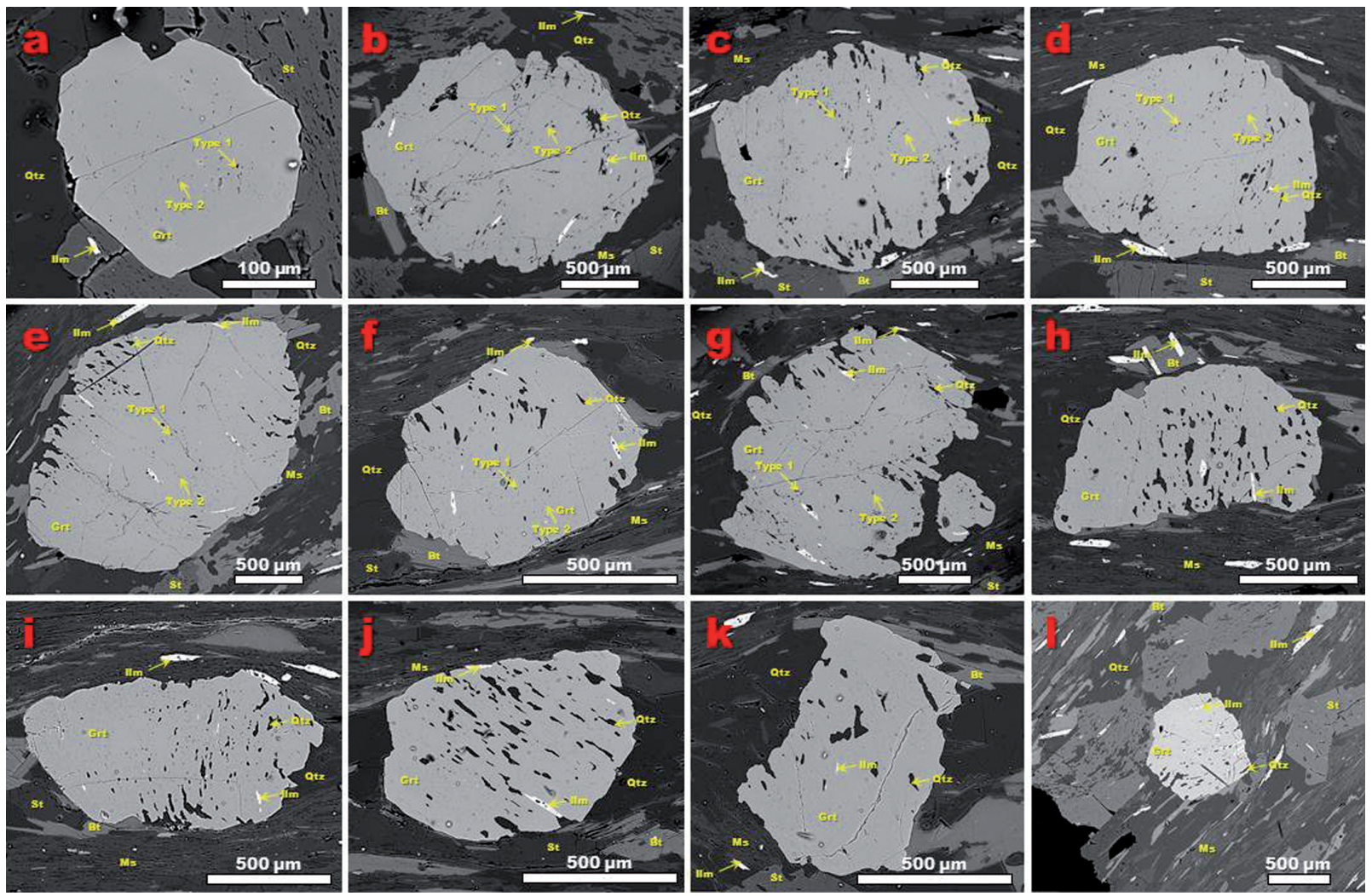

FIGURE 5. BSE images of textural types of garnet: idioblastic textural sector-zoned garnet (a); textural sector- and sigmoidalzoned garnet porphyroblasts of (b)-(e) pseudo-hexagonal, (f) pseudo-tetragonal and (g) amoeba shape; xenoblastic to subidioblastic garnet porphyroblasts, displaying strong influence of tectonic dissolution (h)-(j); xenoblastic garnet porphyroblast with scarce quartz and ilmenite inclusions without developing a regular pattern of distribution (k); subidioblastic garnet porphyroblast with a pattern of inclusions of quartz and ilmenite $\left(\mathrm{S}_{1}\right)$ concordant to $\mathrm{S}_{2}(\mathbf{l})$.

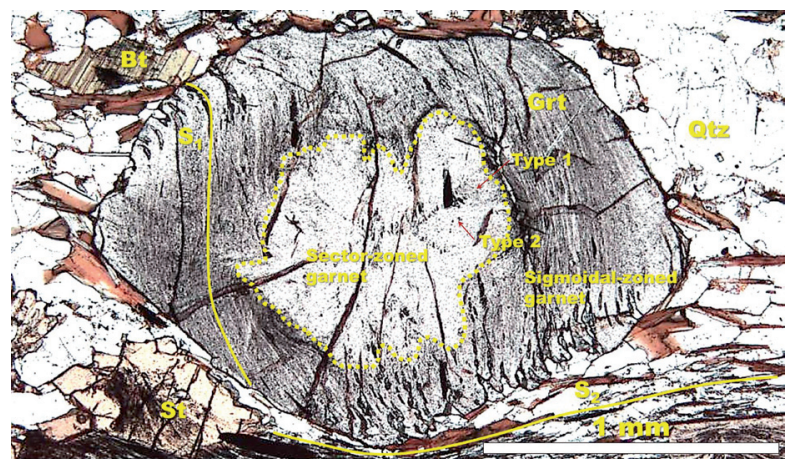

FIGURE 6. Photomicrograph in plane-polarized light showing sector- and sigmoidal-zoned garnet porphyroblast sectioned through the centre. Note the external rim, which grew after sigmoidal-zoned garnet and the main foliation $\left(\mathrm{S}_{2}\right)$ of the rock wrapping around the garnet porphyroblasts, developing strain pressure shadows.

Domal accumulations of graphite reported in previous studies (e.g., Andersen, 1984; Burton, 1986; Kohn, 2004; Wilbur and Ague, 2006; Stowell et al., 2011) were not observed at the end of the intergrowths on garnet $\{110\}$ crystal faces. Andersen (1984) interpreted the intergrowths to reflect non-coherent lattice bonding between quartz and garnet, with quartz added continuously during the growth process of garnet, probably nucleating from type 1 inclusions. He attributed the development of these textures to relatively rapid growth at high levels of super-saturation, but below that needed for dendritic growth; intergrowths were thought to have developed along lattice defects within the garnets which grew by cellular solidification. However, Burton (1986) rejected Andersen's model for the development of intergrowths, arguing that this would not produce tubular quartz intergrowths. Instead, he suggested that either a symplectite growth model (Spry, 1969) or a dislocation growth model (Frank, 1951), or a combination of both, operated.

The textural difference between the graphite-rich and -free bands observed in garnet can be attributed to the lowering of the solubility of quartz in $\mathrm{CO}_{2}$-rich fluids (Burton, 1986). As a result quartz moves only a relatively short distance during garnet growth before being precipitated continuously between growing garnet lineages (Rice and 
Mitchell, 1991). However, according to Rice and Mitchell (1991), neither Andersen (1984) nor Burton (1986) considered the development of textural sector-zoning to be of importance in their models; both authors were more concerned with the origin of the type 2 intergrowths and the growth mechanism of the intervening garnet lineages. They also consider that sector-zoned garnet forms by lineage growth normal to the crystal faces, which promotes the development of several distinctive textures, including type 1 inclusions and type 2 inclusions (intergrowths), all of which are directly or indirectly related to displacement growth. However, in the analyzed garnet-bearing San Lorenzo Schists, no evidence of displacement growth, as both cleavage domes and more massive accumulations at the porphyroblast margins can be supported in this study. Therefore, there is no clear textural interrelationship between the development of textural sector-zoning and the presence of matrix displacement, and is difficult to establish the occurrence of cleavage domes, except by a local development of dome shaped solid graphite accumulations. An explanation for this is that in sector-zoned garnets formed in terranes of regional metamorphism (e.g., metamorphic sequence of the San Lorenzo Schists), post-displacement stresses may have destroyed any cleavage domes as suggested by Rice and Mitchell (1991). According to them, there is a relationship between the presence of graphite within rocks, the formation of textural sectorzoning in porphyroblasts of garnet, the development of lineage structures and/or type 2 intergrowths and the displacement of insoluble matrix grains (typically the graphite).

The outer zone usually display a curved graphite-rich inclusion pattern, concave towards the garnet inner zone and meeting at the pyramid interfaces, which can display a sigmoidal pattern. A relationship between a $\{100\}$ plane and the external schistosity $\left(\mathrm{S}_{1}\right)$ in garnet has been reported in previous studies (e.g., Robyr et al., 2007; Stowell et al., 2011). Robyr et al. (2007) also described later sigmoidal deformational features in garnet, which is compatible with the fact that garnet lattice orientation may not be random and can be controlled by foliation orientation during nucleation and/or deformation.

A similar relationship between the inner and outer zones in irregular-shape type garnet has been described by Miyashita (1996). Garnet porphyroblasts display an inner sector-zoned texture, which is overgrown by curved or sigmoidal foliation in the outher zone. FIGURE 7 illustrates a high resolution backscattered electron (BSE) image mosaic, with three areas of interest, which shows the textural relationships of type 1 and 2 inclusions in the garnet of the San Lorenzo Schists.

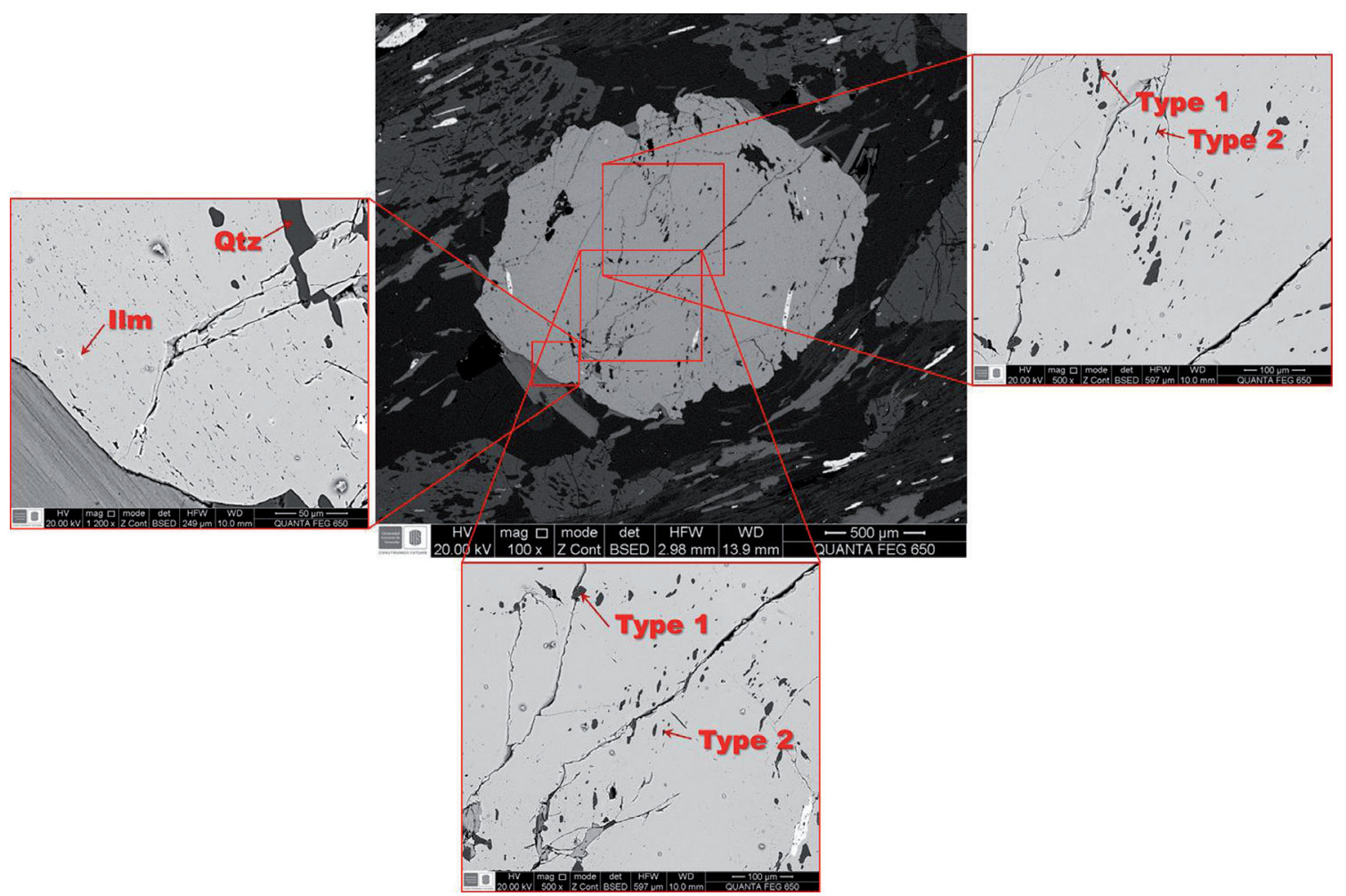

FIGURE 7. High resolution BSE image mosaic, detailing the textural relationships of type 1 and 2 inclusions in sector-zoned garnet of the San Lorenzo Schists. 


\section{Mineral chemistry}

The high resolution BSE image mosaic in FIGURE 8 shows the textural relationships between sector-zoned garnet and associated mineral phases with semiquantitative analysis at different points. EDS allowed us to identify what those particular elements are and their relative proportions in the mineral phases that constitute the sector-zoned garnet in the garnet-staurolite-bearing micaschist.

EDS of almandine-rich garnet (1-2) indicates that it shows from core to rim: $26.33-26.45 \mathrm{wt} \% \mathrm{SiO}_{2}, 15.07-15.19$ wt $\% \mathrm{Al}_{2} \mathrm{O}_{3}, 44.65-51.00$ wt $\% \mathrm{Fe}_{2} \mathrm{O}_{3}$, with minor $\mathrm{MnO}$ (8.17-3.24 wt\%), $\mathrm{CaO}(5.08-2.56 \mathrm{wt} \%)$ and $\mathrm{MgO}(0.70-$
$1.57 \mathrm{wt} \%)$. EDS of staurolite (3) reveals the presence of $24.71 \mathrm{wt} \% \mathrm{SiO}_{2}, 45.13 \mathrm{wt} \% \mathrm{Al}_{2} \mathrm{O}_{3}, 27.77 \mathrm{wt} \% \mathrm{Fe}_{2} \mathrm{O}_{3}$, with minor $\mathrm{MgO}(1.39 \mathrm{wt} \%)$ and $\mathrm{TiO}_{2}(1.01 \mathrm{wt} \%)$. EDS of muscovite (4) indicates the presence of $\mathrm{SiO}_{2}(48.78$ wt $\%), \mathrm{Al}_{2} \mathrm{O}_{3}(36.95 \mathrm{wt} \%), \mathrm{K}_{2} \mathrm{O}(12.49 \mathrm{wt} \%), \mathrm{Na}_{2} \mathrm{O}(1.19$ wt\%), with minor $\mathrm{MgO}(0.58 \mathrm{wt} \%)$. EDS of biotite (5) indicates the presence of $\mathrm{SiO}_{2}(31.35 \mathrm{wt} \%), \mathrm{Al}_{2} \mathrm{O}_{3}(16.36$ $\mathrm{wt} \%), \mathrm{Fe}_{2} \mathrm{O}_{3}(31.95 \mathrm{wt} \%), \mathrm{K}_{2} \mathrm{O}(9.88 \mathrm{wt} \%)$ and $\mathrm{MgO}$ (8.16 wt\%), with minor Ti (2.30 wt\%). EDS of quartz (6) reveals that it mainly consists of $\mathrm{SiO}_{2}(100.00 \mathrm{wt} \%)$. EDS of ilmenite (7) shows the characteristic intensity peaks for $\mathrm{TiO}_{2}(49.51 \mathrm{wt} \%)$ and $\mathrm{FeO}(50.49 \mathrm{wt} \%)$. EDS analyses are in agreement with literature data (Marshall, 2013)
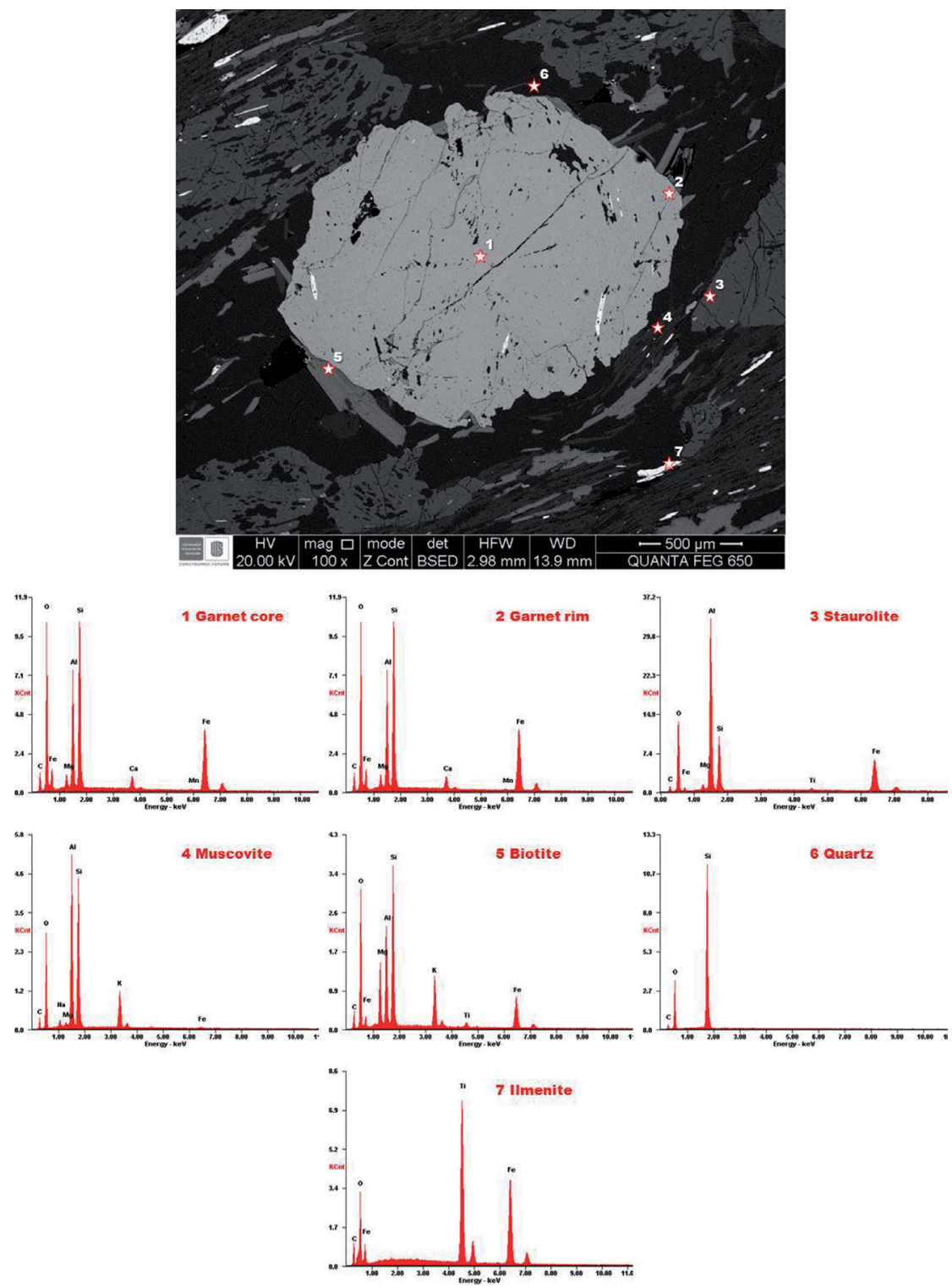

FIGURE 8. High resolution BSE image mosaic and EDS at the marked stars on the image of the textural relationships between sector-zoned garnet and associated mineral phases in the San Lorenzo Schists. The appearance of carbon is attributed to the carbon coating on the sample before SEM analysis. 


\section{Garnet chemical zoning}

Oscillatory and sector-zoning cannot be related here to textural sector- and sigmoidal-zoned garnet from the metapelitic rocks of the San Lorenzo Schists. Chemical zoning maps of the elements iron $(\mathrm{Fe})$, magnesium $(\mathrm{Mg})$, calcium $(\mathrm{Ca})$ and manganese $(\mathrm{Mn})$ are shown in FIGURE 9, which reveals that garnet displays a complex zoning and amoeba-like shape. The decreasing $\mathrm{Mn}$ indicates that zoning resulted from growth partitioning between garnet and matrix
(Hollister, 1966), followed by minor modification by diffusion near the rim. Amoeba-like zoned garnet shows a similar chemical zoning for $\mathrm{Mn}$ as that reported by Castellanos et al. (2010). According to Daniel and Spear (1998), it can reveal multiple nuclei formed simultaneously in the core region, with nuclei expanding by growth in amoeba-shape forms along preexisting mineral grain boundaries. However, it is not clear that there are distinct nuclei taking into account the Ca distribution in garnet.
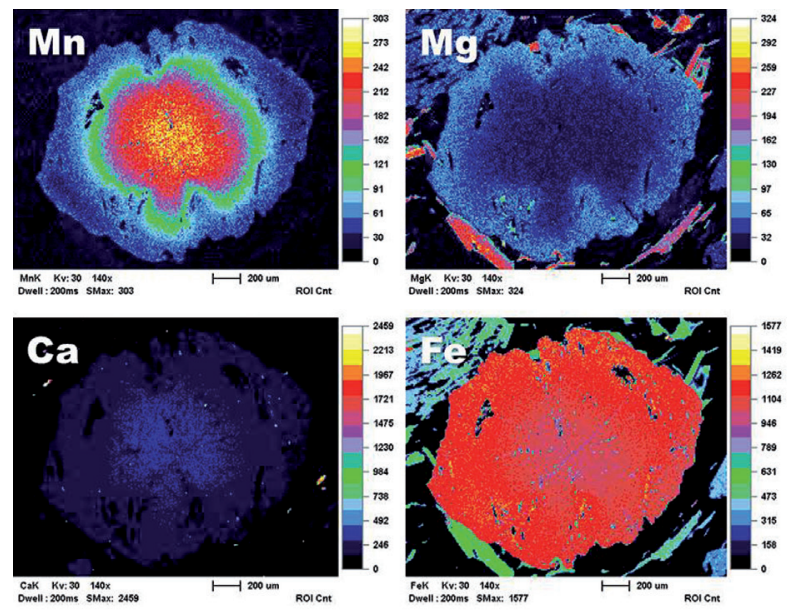

MgkK Kw:30 $140 x$

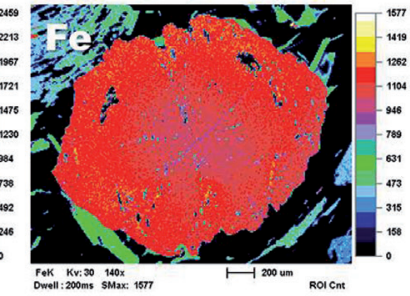

a
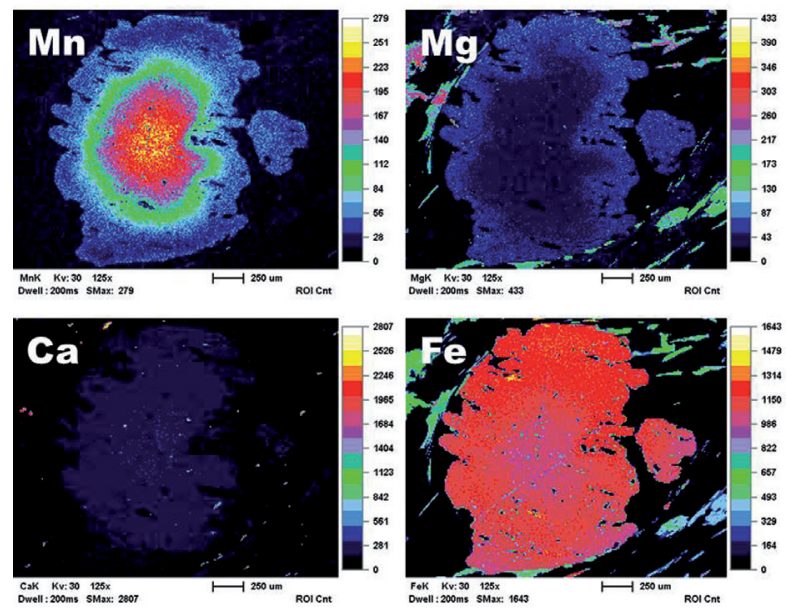

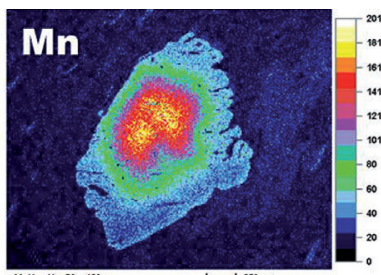

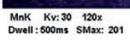
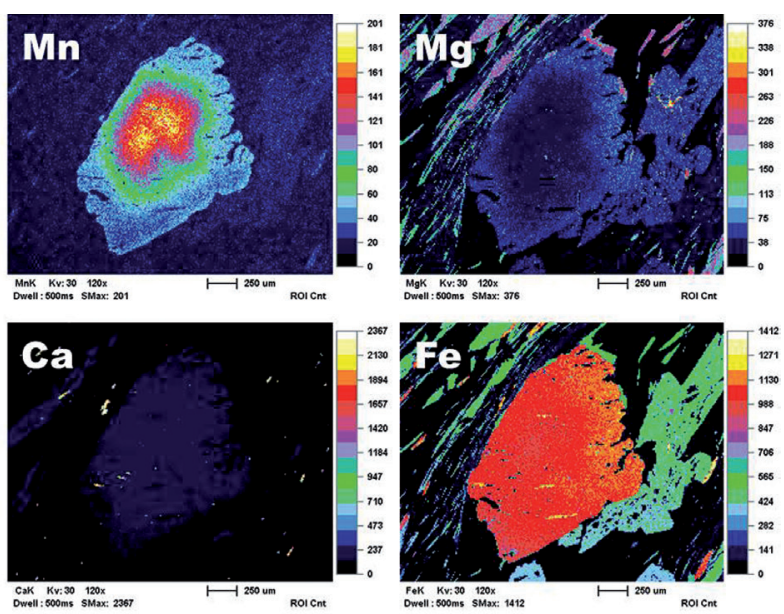

b
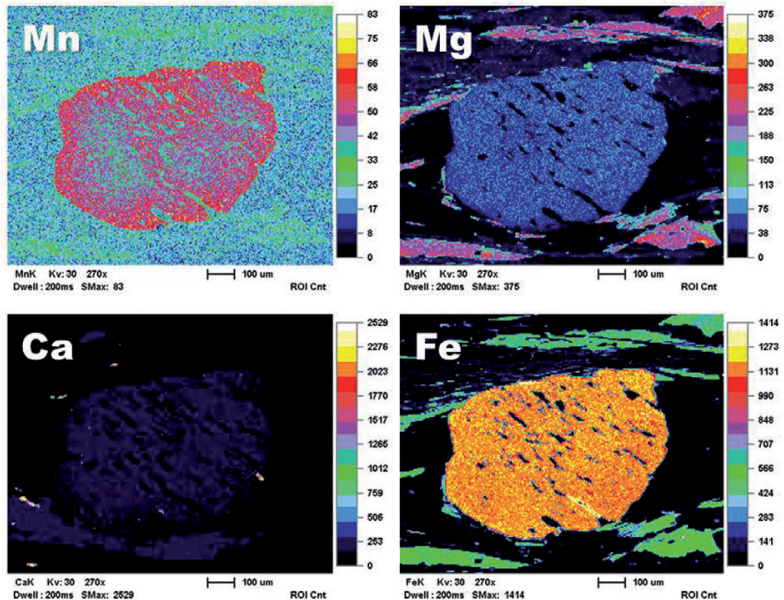

d

FIGURE 9. $\mathrm{Mn}, \mathrm{Mg}, \mathrm{Ca}$ and Fe compositional maps of garnet crystals and associated mineral phases; warm colors show areas of high concentration whereas cool colors represent areas of low concentration (black color indicates very low concentration): (a) pseudo-hexagonal garnet displaying patchy normal zoning; (b) garnet with patchy normal zoning broken by tectonic dissolution; (c) two generations of garnet, with the large garnet of amoeba shape showing patchy normal zoning whereas the small garnet not and (d) garnet displaying strong tectonic dissolution, slight normal zoning and straight quartz and ilmenite trails at approximately $30^{\circ}$ to the main schistosity of the rock. 
$\mathrm{X}$-rays generated by scanning the electron beam across the sample can be used to produce EDS mapping, which provides in addition to the BSE image a meaningful picture of the elemental distribution of a mineral phase, although it will only give a qualitative image of the distribution of elements. The elemental mapping shows a prograde zoning pattern with respect to $\mathrm{Mn}$, which decreases from core to rim. Mg shows a reversal behavior regarding to $\mathrm{Mn}$, increasing from core to the rim, which is typical from a prograde path. $\mathrm{Ca}$ and $\mathrm{Fe}$ do not reveal clearly the sector-zoning in garnet.

Petrological investigations of zoned garnet have played a key role in obtaining information on the mineral chemistry equilibria developed during the PT evolution of metamorphic rocks, and garnet is one of the most suitable minerals since, due to its slow cation diffusion, is able to preserve shells with an original chemical composition (Ague and Carlson, 2013), often accompanied by a rapid growth after nucleation, allowing the inclusion of syn-kinematically matrix minerals (Ortolano et al., 2014).

FIGURE 9 displays a concentric normal zoning for $\mathrm{Mn}$, which reflects progressive depletion from the core to the rim, documenting an example of rapid intergranular diffusion of $\mathrm{Mn}$. According to Ague and Carlson (2013), this can be attributed to partial chemical equilibrium. However, the chemical zoning tends to show a pseudo-dendritic morphology, which is indicative of interfacecontrolled growth from a highly supersaturated fluid. Therefore, garnet zoning serves as a monitor of the length scales of intergranular diffusion and of the degree of chemical equilibrium achieved during crystallization (Ague and Carlson, 2013). The major cations $\mathrm{Mg}, \mathrm{Fe}, \mathrm{Ca}$, and $\mathrm{Mn}$ diffuse within the dodecahedral crystal of garnet. This is multicomponent diffusion, in which all elements can undergo diffusion at the same time. Thus, diffusion of a single element cannot be treated independently of the others. For example, if $\mathrm{Mg}$ diffuses out of some domain in a garnet, some combination of $\mathrm{Fe}, \mathrm{Ca}$, and/or Mn must diffuse in to maintain stoichiometry. Garnet rims show evidence of cation exchange with matix phases, such as biotite with decreasing temperature, revealed by a decrease in $\mathrm{Mg} / \mathrm{Fe}$ during retrograde exchange and the small reversal zoning in $\mathrm{Mn}$ at the rim.

\section{DISCUSSION ON RELATIVE TIMING OF DEFORMATION AND GARNET GROWTH}

Metamorphic minerals, such as garnet, can grow at any stage relative to deformation phases, with garnet porphyroblasts containing inclusions that develop an internal foliation $\left(\mathrm{S}_{1}\right)$, which along with the external foliation $\left(\mathrm{S}_{2}\right)$ can provide very useful information on the relative timing of garnet growth during deformation and metamorphism. However, to understand the conditions during deformation, we must determine the relative timing of metamorphism with respect to deformation. According to the Andersen's (1984) classification, the inclusion and intergrowth patterns in garnets may be divided in two categories, taking into account their shape and orientation and the crystallography of the garnet host (FIGURE 10).

A two-step growth textural sector- and sigmoidalzoned garnet from the San Lorenzo Schists (Sierra Nevada de Santa Marta massif) is discussed in this study. Petrographic evidence indicates that these rocks show complex deformation history. A number of distinctive microstructural and textural features are displayed by garnet porphyroblasts, with an inner zone (sector-zoning) containing quartz, ilmenite and graphite inclusions and an outer zone (sigmoidal-zoning) overgrowing an early schistosity developing a sigmoidal pattern with inclusions of quartz, ilmenite and graphite (FIGURES 6, 11). The most significant difference between the inner and outer zones of garnet is not only the abrupt increase in the number of graphite and, to a lesser extent, quartz inclusions in the outer zone, but also the change from the growth of garnet with inclusions only at the boundaries of $\{110\}$ sectors to the growth of garnet with multiple inclusions having a sigmoidal pattern.

Garnet shows well-defined inclusion patterns and temporal constraints could be placed on garnet growth. Taking into account the deformation relationships, inclusion trails pattern and foliation relationships, we divide garnet into textural inner and outer zones, suggesting a sketch of the evolution of a two-step growth of textural sector- and sigmoidalzoned garnet in metapelitic rocks of the San Lorenzo Schists, as shown in FIGURE 12. Two early phases of deformation during crustal thickening $\left(\mathrm{D}_{1}\right.$ and $\left.\mathrm{D}_{2}\right)$ can be observed. 


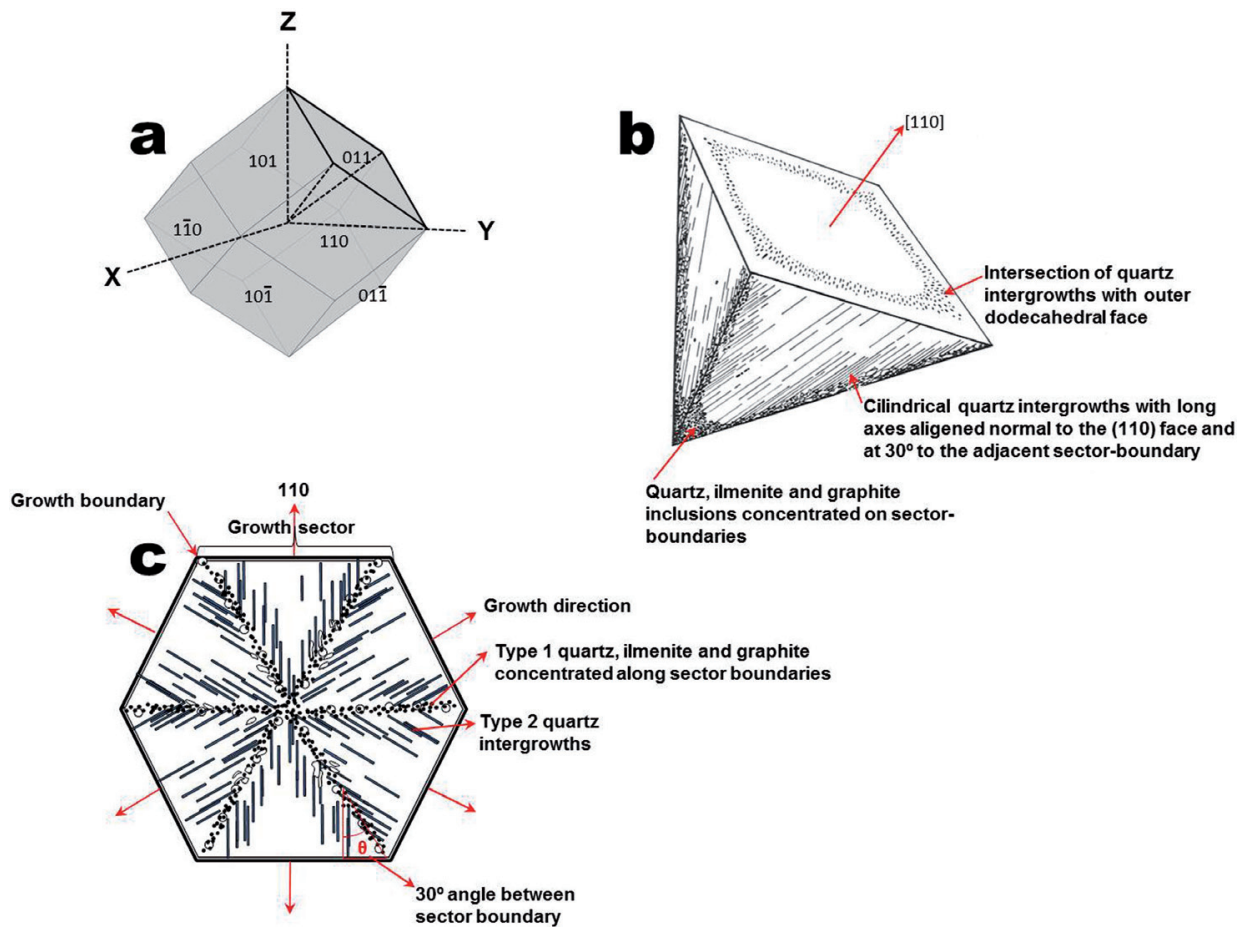

FIGURE 10. (a) External morphology of a rhombododecahedral garnet crystal bounded by $\{110\}$ crystal faces. (b) Schematic growth pyramid of garnet, showing inclusion and intergrowth geometry. Synoptically the garnet is made up of twelve such pyramids, with common apices at the centre of the crystal and bases formed by the $\{110\}$ crystal faces. (c) Sketch section through garnet centre showing the relationship of the inclusion and intergrowth pattern to the crystallography of the garnet host. Adapted and modified from Burton (1986).

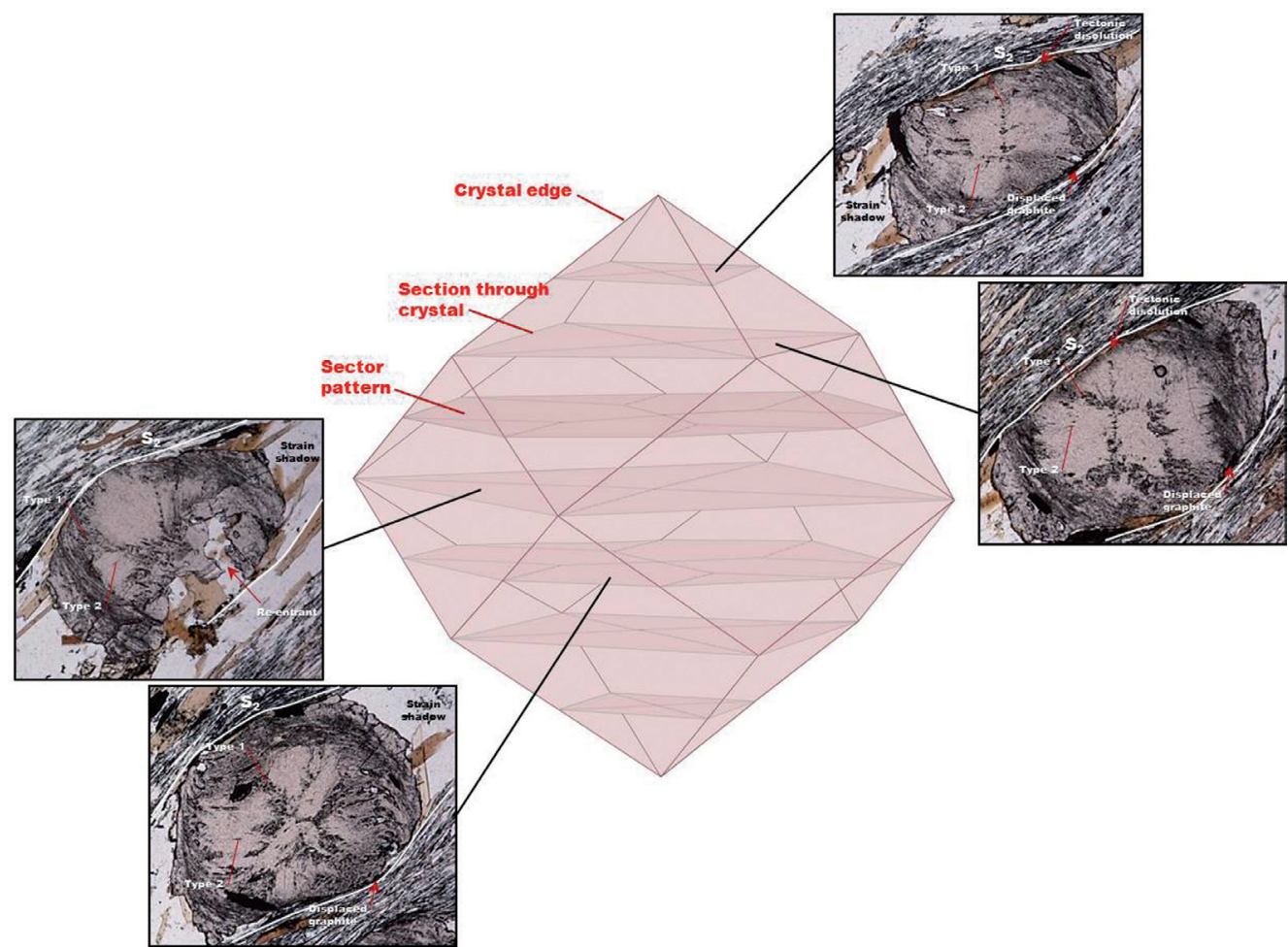

FIGURE 11. Rhombododecahedral garnet crystal, displaying several photomicrographs of the sector patterns developed on a series of sections through garnet. 
Step 1

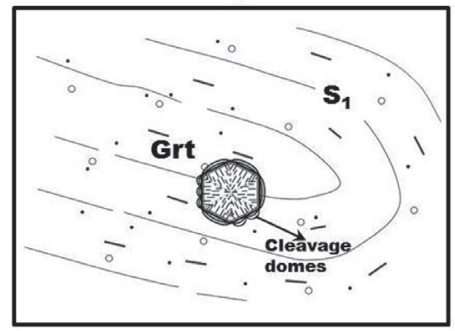

Garnet growth during $D_{1}\left(S_{1}\right)$ in a matrix composed of mica, graphite and quartz, developing textural sector zoning and cleavage domes
Step 2

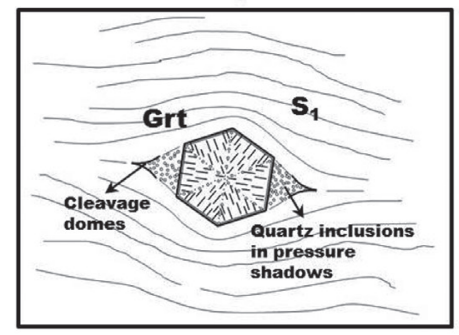

Textural sector zoned garnet growth during $D_{1}\left(S_{1}\right)$, developing strain pressure shadows and shearing away cleavage domes
Step 4

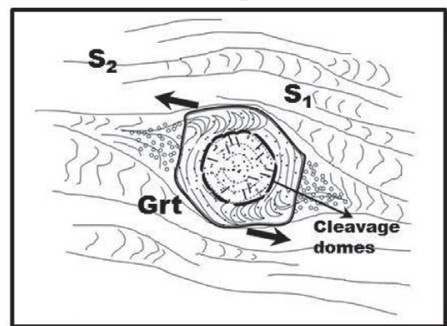

Sigmoidal garnet overgrowing textural sector zoned garnet growth and cleavage domes during $D_{2}\left(S_{2}\right)$

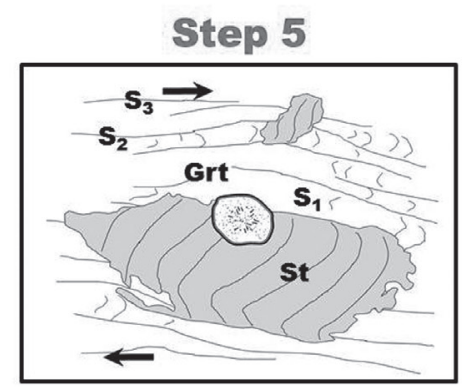

Post-tectonic growing of sigmoidal staurolite, post- $D_{2}$

$\left(S_{2}\right)$ and pre- $D_{3}\left(S_{3}\right)$
Step 3

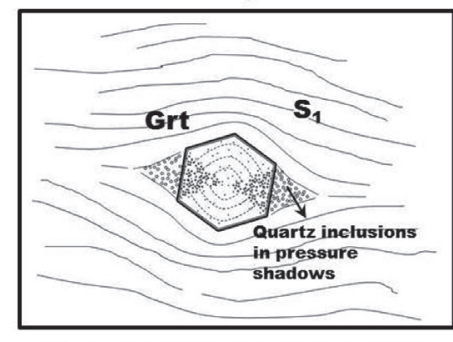

Textural sector zoned garnet growth during $D_{1}\left(S_{1}\right)$, with quartz inclusions derived from strain pressure shadows

FIGURE 12. Generalized sketch of the evolution of garnet from the San Lorenzo Schists.

During step 1, garnet growth occurred syn-D $\left(\mathrm{S}_{1}\right)$, developing textural sector-zoning and cleavage domes, which requires rapid crystal growth (e.g., Andersen, 1984; Burton, 1986; Kohn, 2004). However, according to Olimpio and Anderson (1978), the low density of graphite (and quartz) inclusions in the inner zone indicates that growth may have been sufficiently slow for graphite to diffuse ahead of the growing interface. Conversely, the motion of the interface may have been controlled by the rate at which graphite diffused away, which appears to have been the case where curved laminae of graphite formed along the outer zone. The presence of graphite in nearly all rocks containing texturally sector-zoned garnets appears to be more significant and has been mentioned by several authors (e.g., Burton, 1986; Hollister, 1970; Olimpio and Anderson, 1978), which can be proved in the studied sector-zoned garnets of the San Lorenzo Schists. A relict $\mathrm{S}_{1}$ schistosity defined by the orientation of biotite in the matrix and quartz, ilmenite and graphite inclusions in garnet can be observed, although it was strongly modified during progressive metamorphism. However, during this step, the late emplacement of syn-tectonic gabbroic rocks of the Santa Marta Batholith close to the peak of regional metamorphism, which exhibit concordant relationships with the metapelitic rocks of the San Lorenzo Schists and magmatic foliation similar to that reported by González (1999). They produced a local and abrupt heating of these metapelitic rocks, promoting a rapid nucleation of sectorzoned garnets during disequilibrium growth conditions.

According to Burton (1986), type 1 inclusions are concentrated along growth sector boundaries, parallel to the $\{110\}$ crystallographic planes, which define the trace of the intersection surface between two adjacent $\{110\}$ crystal faces as they grew from the garnet centre. Such individual inclusions consist of quartz, ilmenite and graphite, defining this pattern, represent relicts of the matrix, which is sometimes suggested by their gradual coarsening towards the margins of the garnets, an indication of prograde coarsening of the matrix (Rice and Mitchell, 1991). Type 2 intergrowths of quartz which unlike the inclusions concentrated on the sector boundary planes, are not relicts of the matrix, but were formed simultaneously with the growing garnet; they originate at the sector boundaries with the long axes normal to the $\{110\}$ crystal faces (Burton, 1986). Cleavage domes and growth sector-zoning have been interpreted as the 
result of growth in local stress fields developed under bulk hydrostatic conditions (Ferguson, 1980). However, the significance of graphite should be treated carefully, taking into account that syn-tectonic sigmoidal-zoned garnets have been reported from graphitic schists in many areas, some of them adjacent to areas with texturally sector-zoned garnets (e.g., MacQueen and Powell, 1977), reflecting the dependence of the development of all these textures on the presence of a hydrostatic stress field. A similar case can be documented in the sigmoidal-zoned garnet from the San Lorenzo Schists.

The step 2 was characterized by a textural sector-zoned garnet growth during $\mathrm{D}_{1}\left(\mathrm{~S}_{1}\right)$, developing strain pressure shadows and shearing away cleavage domes. The step 3 was also characterized by a textural sector-zoned garnet growth during $D_{1}\left(S_{1}\right)$, with quartz inclusions derived from strain pressure shadows and the $\mathrm{S}_{1}$ schistosity wrapping around garnet porphyroblasts. During step 4, a sigmoidal-zoned garnet overgrowth occurred after textural sector-zoned garnet growth and cleavage domes during $\mathrm{D}_{2}\left(\mathrm{~S}_{2}\right)$. A crenulated structure was developed, with the $\mathrm{S}_{2}$ schistosity wrapping around the garnet porphyroblast. Sigmoidal inclusion trails, like those observed in garnet, are traditionally interpreted as evidence for syn-kinematic porphyroblast growth (e.g., Schoneveld, 1977), and, therefore, can be considered as an explicit shear-sense indicator, which has been used extensively to interpret the tectono-metamorphic history of metamorphic rocks (Robyr et al., 2009), and is of particular significance in structural geology. Step 5 is represented by a post-tectonic growing of sigmoidalzoned staurolite, post- $\mathrm{D}_{2}\left(\mathrm{~S}_{2}\right)$ and pre- $\mathrm{D}_{3}\left(\mathrm{~S}_{3}\right)$.

Based in textural features and chemical zoning, two different types of garnets were recognized; sector- and sigmoidal-zoned garnet. In some cases they seem to show an external rim, which grew after sigmoidal texture. These facts suggest that growing processes for sector-zoning garnet can be interpreted as a non-equilibrium stage of progressive metamorphism, followed by the growing of sigmoidal-zoned garnet at the last stage of this event. However, textural observations coupled with the style of deformation in adjacent rocks, suggest that these garnets grew under active deformation (wraps and dislocations) rather than hydrostatic conditions (Boyke, 2013).

Chemical zoning of garnet from the San Lorenzo Schists (FIGURE 9) reveals (1) tectonic dissolution of garnet in progressive shear zones, which explain the chemical zoning of garnet abruptly truncated against the main metamorphic foliation of the rock, and (2) alteration due to subsequent garnet resorption under (apparently) static conditions.
There is no doubt that further petrological, geochemical and geochronological data are necessary for a better understanding of the mechanism of nucleation and two- step growth of sector- and sigmoidal-zoned garnet during the tectono-metamorphic evolution of the San Lorenzo Schists, which is also very important to develop a quantitative understanding of orogenic processes, determining metamorphic PT conditions by means of mineralogical geothermobarometry, electron probe microanalysis of coexisting minerals, and paragenetic and thermodynamic analysis of mineral equilibria. Combined with earlier results, these studies will provide a framework for understanding the geologic tectonic development and the metamorphic evolution of the Sierra Nevada de Santa Marta.

\section{CONCLUSIONS}

The two-step growth garnet from the San Lorenzo Schists can be interpreted as a complex growing process, with sector-zoning garnet as a non-equilibrium stage of progressive metamorphism, followed by sigmoidal-zoning garnet growth at the last stage of this event. Foliated gabbroic rocks of the Santa Marta Batholith exhibit concordant relationships with the middle- to high-grade metamorphic rocks, including the San Lorenzo Schists, and may be interpreted as syn-tectonic intrusives emplaced at close to the peak metamorphism. Further petrological, geochemical and geochronological data are necessary for a better understanding of the mechanism of nucleation and growth of garnet during the tectono-metamorphic evolution of the San Lorenzo Schists, which is also very important to develop a quantitative understanding of orogenic processes, providing a framework for understanding the geologic tectonic development and the metamorphic evolution of the Sierra Nevada de Santa Marta.

\section{ACKNOWLEDGEMENTS}

The authors acknowledge to the Laboratory of Microscopy of the Universidad Industrial de Santander and the Transmitted Light Microscopy laboratories of the Universidad Industrial de Santander and Universidad de Pamplona for the use of research facilities and the professional staff of these labs for assistance with data acquisition. The authors also acknowledge to the anonymous referees for their critical and insightful reading of the manuscript and are most grateful to the above-named people and institutions for support.

\section{REFERENCES}

Ague, J.J., and Carlson, W.D. 2013. Metamorphism as Garnet Sees It: The Kinetics of Nucleation and Growth, 
Equilibration, and Diffusional Relaxation. Elements, 9(6): 439-445.

Akizuki, M. 1984. Origin of optical variations in grossular andradite garnet. American Mineralogist, 69: 328-338.

Andersen, T.B. 1984. Inclusion patterns in zoned garnets from Magerfy, north Norway. Mineralogical Magazine, 48: 21-26.

Argles, T.W., Prince, C.I., Foster, G.L., and Vance, D. 1999. New garnets for old? Cautionary tales from young mountain belts. Earth and Planetary Science Letters, 172: 301-309.

Bell, T.H., Rubenach, M.J., and Fleming, P.D. 1986. Porphyroblast nucleation, growth and dissolution in regional metamorphic rocks as a function of deformation partitioning during foliation development. Journal of Metamorphic Geology, 4(1): 37-67.

Bell, T.H., Hickey, K.A., and Wang, J. 1997. Spiral and staircase inclusion trail axes within garnet and staurolite porphyroblasts from schists of the Bolton Syncline, Connecticut: timing of porphyroblast growth and the effects of fold development. Journal of Metamorphic Geology, 15(4): 467-478.

Bestmann, M., Habler, G., Heidelbach, F., and Thöni, M. 2008. Dynamic recrystallization of garnet and related diffusion processes. Journal of Structural Geology, 30(6): 777-790.

Boyle, A.P. 2013. Controls on Growth of Quartz in Garnet Porphyroblasts. Consulted on 25 November, 2014. http://pcwww.liv.ac.uk/microstr/aziz.html

Burton, K. 1986. Garnet-quartz intergrowths in graphitic pelites: the role of the fluid phase, Mineralogical Magazine, 50: 611-620.

Bustamante, C., Cardona, A., Saldarriaga, M., GarcíaCasco, A., Valencia, V., y Weber, M. 2009. Metamorfismo de los esquistos verdes y anfibolitas pertenecientes a los Esquistos de Santa Marta, Sierra Nevada de Santa Marta (Colombia): ¿Registro de la colisión entre el arco Caribe y la margen Suramericana?. Boletín de Ciencias de la Tierra, 25: 7-26.

Cardona, A., Cordani, U.G., and MacDonald, W.D. 2006. Tectonic correlations of pre-Mesozoic crust from the northern termination of the Colombian Andes, Caribbean region. Journal of South American Earth Sciences, 21: 337-354.
Cardona, A., Valencia, V., Bustamante, C., García-Casco, A., Ojeda, G., Ruiz, J., Saldarriaga, M., and Weber, M. 2010. Tectonomagmatic setting and provenance of the Santa Marta Schists, Northern Colombia: insights on the growth and approach of Cretaceous Caribbean oceanic terranes to the South American continent. Journal of South American Earth Sciences, 29: 784-804.

Castellanos, O.M. 2001. Chemical composition of the rock-forming minerals in the Silgara formation and P-T conditions in the Mutiscua area, Santander Massif, Eastern Cordillera, Colombia. MSc thesis, Shimane University (Japan).

Castellanos, O.M., Ríos, C.A., and Takasu, A. 2004. Chemically sector-zoned garnets in the metapelitic rocks of the Silgará Formation in the Central Santander Massif, Colombian Andes: Occurrence and growth history. Boletín de Geología, 26: 9-18.

Castellanos, O.M., Ríos, C.A., and Takasu, A. 2010. X-ray color maps of the zoned garnets from Silgará Formation metamorphic rocks, Santander Massif, Eastern Cordillera (Colombia). Earth Science Research Journal, 14: 161-172.

Cordani, U.G., Cardona, A., Jiménez, D.M., Liu, D., and Nutran, A.P. 2005. Geochronology of Proterozoic basement inliers in the Colombian Andes: tectonic history of remnants of a fragmented Grenville belt. In: Vaughan, A.P.M., Leat, P.T., Pankhurst, R.J. (eds). Terrane Processes at the Margins of Gondwana. Geological Society, London, Special Publications 246: 329-346.

Daniel, C.G., and Spear, F.S. 1998. Three-dimensional patterns of garnet nucleation and growth. Geology, 26: 503-506.

Den Brok, B., and Kruhl, J.H. 1996. Ductility of garnet as an indicator of extremely high temperature deformation: Discussion. Journal of Structural Geology, 18(11): 1369-1373.

Doolan, B.L. 1970. The structure and metamorphism of the Santa Marta area Colombia, South America. PhD thesis, State University of New York (USA).

Frank, F.C. 1951. Capillary equilibria of dislocated crystals. Acta Crystallographica, 4: 497-501.

Ferguson, C.C. 1980. Displacement of inert mineral grains by growing porphyroblasts: A volume balance constraint. Contributions to Mineralogy and Petrology, 91: 541-544. 
Florence, F.P., and Spear, F.S. 1993. Influences of reaction history and chemical diffusion on P-T calculations for staurolite schists from the Littleton Formation, northwestern NewHampshire. American Mineralogist, 78: 345-359.

González, G. 1999. Mecanismo y profundidad de emplazamiento del Plutón de Cerro Cristales, Cordillera de la Costa, Antofagasta, Chile. Revista Geológica de Chile, 26: 43-66.

Gray, N.H., and Busa, M.D. 2007. The threedimensional geometry of simulated porphyroblast inclusion trails: inert-marker, viscous-flow models. Journal of Metamorphic Geology, 12: 575-587.

Hollister, L.S. 1966. Garnet zoning: an interpretation based on the Rayleigh fractionation model. Science, 154: $1647-1651$.

Hollister, L. 1970. Origin, mechanism, and consequences of compositional sector-zoning in staurolite. American Mineralogist, 55: 742-766.

Ikeda, T., Shimobayashi, N., Wallis, S.R., and Tsuchiyama, A. 2002. Crystallographic orientation, chemical composition and three-dimensional geometry of sigmoidal garnet: evidence for rotation. Journal of Structural Geology 24: 1633-1646.

Kiers, J. 2013. Analysis of the timing of deformation, porphyroblast growth and metamorphic conditions in the Lukmanier Pass area, Switzerland: Implications for the origin of metamorphism in the Central Alps. Msc Thesis, Utrecht University (Netherlands).

Kim, H.-S., and Jung, W.-S. 2010. The use of garnet porphyroblasts to resolve the metamorphic pressuretemperature-deformation $(\mathrm{P}-\mathrm{T}-\mathrm{d})$ path: An example from the Imjingang belts, South Korea. Geosciences Journal, 14(2): 111-126.

Kitamura, M., Wallis, S., and Hirajima, T. 1993. Sector zoning and surface roughening of garnet in the Sambagawa metamorphic rock, Proceedings 6th Topic. Meet. Crystal Growth Mechanism, pp. 215-220.

Kohn, M.J. 2004. Oscillatory- and sector-zoned garnets record cyclic (?) rapid thrusting in central Nepal. Electronic Journal of Earth Sciences, 5(12): 1-9.

Kretz, R. 1983. Symbols for rock-forming minerals. American Mineralogist, 68: 277-279.
MacQueen, J.A., and Powell, D. 1977. Relationships between deformation and garnet growth in Moine (Precambrian) rocks of western Scotland. Geological Society of America Bulletin, 88: 235-40.

Marshall, D. 2013. Mineral Energy Dispersive Spectra (EDS). Consulted on 15 December, 2013. http://www. sfu.ca/ marshall/sem/mineral.htm.

Masuda, T., and Mochizuki, S. 1989. Development of snowball structure: numerical simulation of inclusion trails during synkinematic porphyroblast growth in metamorphic rocks. Tectonophysics, 170: 141-150.

Meth, Ch.E., and Carlson, W.D. 2005. Diffusioncontrolled synkinematic growth of garnet from a heterogeneous precursor at Passo Del Sole, Switzerland. The Canadian Mineralogist, 43: 157-182.

Miyashita, Y. 1996. Texturally Sector-Zoned Garnet Porphyroblasts in the Ryoke Metamorphic rocks from the Yanai District, Southwest Japan. Journal of Geosciences (Osaka City University), 39: 29-59.

Olimpio, J.O., and Anderson, D.E. 1978. The relationships between chemical and textural (optical) zoning in metamorphic garnets, South Morar, Scotland. American Mineralogist, 63: 677-689.

Ordoñez, O., Pimentel, M.M., and De Moraes, R. 2002. Granulitas de Los Mangos: un fragmento grenviliano en la parte SE de la Sierra Nevada de Santa Marta: Revista Academia Colombiana de Ciencias, 26: 169-179.

Ortolano, G., Visalli, R., Cirrincione, R., and Rebay G. 2014. PT-path reconstruction via unraveling of peculiar zoning pattern in atoll shaped garnets via image assisted analysis: An example from the Santa Lucia del Mela garnet micaschists (Northeastern Sicily-Italy). Periodico di Mineralogia, 83(2): 257-297.

Ratner, J.E., and Cheney, J.T. 2002. The evolution of the Cycladic subduction complex: constraining p-t-t path geometry from compositional zoning and mineral inclusions within garnet in pelitic schists from Syros, Cyclades, Greece. Geological Society of America, Abstracts with Programs, 34(1), p.A.67.

Restrepo-Pace, P.A., Ruiz, J., Gehrels, G., and Cosca, M. 1997. Geochronology and Nd isotopic data of Grenvilleage rocks in the Colombian Andes: new constraints for late Proterozoic-early Paleozoic paleocontinental reconstructions of the Americas. Earth and Planetary Science Letters, 150: 427-441. 
Rice, A., and Mitchell, J. 1991. Porphyroblast textural sector-zoning and matrix displacement. Mineralogical Magazine, 55: 379-396.

Rice, A., Habler, G., Carrupt, E., Cotza, G., Wiesmayr, G., Schuster, R., Sölva, H., Thöni, M., and Koller, F. 2006. Textural Sector-Zoning in Garnet: Theoretical Patterns and Natural Examples from Alpine Metamorphic Rocks. Australian Journal of Earth Sciences, 6: 70-89.

Robyr, M., Vonlanthen, P., Baumgartner, L.P., and Grobety, B. 2007. Growth mechanism of snowball garnets from the Lukmanier Pass area (Central Alps, Switzerland): a combined uCT/EPMA/EBSD study. Terra Nova, 19: 240-244.

Robyr, M., Carlson, W.D., Passchier, C., and Vonlanthen, P. 2009. Microstructural, chemical and textural records during growth of snowball garnet. Journal of Metamorphic Geology, 27(6): 423-437.

Schoneveld, C. 1977. A study of some typical inclusion patterns in strongly paracrystalline-rotated garnets. Tectonophysics, 39: 453-471.

Sepahi, A.A. 2007. A detailed study of morphology and chemistry of garnet crystal with suggestion of new subdivisions: data from pelitic schists, hornfels and aplites of Hamedan Region, Iran. Iranian Journal of Science and Technology Transactions, A 31(A3): 281-289.

Spry, A. 1969. Metamorphic Textures. Pergamon Press, Oxford, 350p.

Stallard, A., and Hickey, K.A. 2002. A comparison of microstructural and chemical patterns in garnet from the Fleur de Lys Supergroup, Newfoundland. Journal of Structural Geology, 24(6): 1109-1123.

Stowell, H., Zuluaga, C., Boyle, A., and Bulman, G. 2011. Garnet sector and oscillatory zoning linked with changes in crystal morphology during rapid growth, North Cascades, Washington. American Mineralogist, 96: 1354-1362.

Takasu, A. 1986. Resorption-overgrowth of garnet from the Sambagawa pelitic schists in the contact aureole of the Sebadani metagabbro mass, Shikoku, Japan. Journal of Geological Society of Japan, 92: 781-792.

Tschanz, C.M., Jimeno, A., and Vesga, C. 1969. Geology of the Sierra Nevada de Santa Marta area (Colombia), Instituto de Investigaciones e Información Geocientífica, Minero-Ambiental y Nuclear, República de Colombia, 288p.
Tschanz, C.M., Marvin, R.F., Cruz, J., Mehnert, H.H., and Cebula, G.T. 1974. Geologic evolution of the Sierra Nevada de Santa Marta, northeastern Colombia. Geological Society of America Bulletin, 85: 273-284.

Vernon, R.H. 1978. Porphyroblast-matrix microstructural relationships in deformed metamorphic rocks. Geologische Rundschau, 67(1): 288-305.

Watson, E.B., and Liang, Y. 1995. A simple model for sector zoning in slowly grown crystals: Implications for growth rate and lattice diffusion, with emphasis on accessory minerals in crustal rocks. American Mineralogist, 80: 1179-1187.

Watson, E.B. 2004. A conceptual model for near-surface kinetic controls on the trace-element and stable isotope composition of abiogenic calcite crystals. Geochimica et Cosmochimica Acta, 68: 1473-1488.

Williams, M.L. 1994. Sigmoidal inclusion trails, punctuated fabric development, and interactions between metamorphism and deformation. Journal of Metamorphic Geology, 12: 1-21.

Wilbur, D.E., and Ague, J.J. 2006. Chemical disequilibrium during garnet growth: Monte Carlo simulations of natural crystal morphologies. Geology, 34: 689-692.

Zhao, G., Liu, Sh., and Liu, X. 2004. Compositional Distribution and Growth Mode of Garnet Porphyroblasts during Deformation and Metamorphism. Acta Geologica Sinica, 78(1): 186-190.

Received: 1 June 2015

Accepted: 29 January 2016

Manuscript published online: 4 February 2016 